\title{
Human induced soil erosion and the implications on crop yield in a small mountainous Mediterranean catchment (SW-Turkey)
}

\author{
Maarten Van Loo ${ }^{\mathrm{a}, *}$, Bert Dusar ${ }^{\mathrm{a}, \mathrm{b}}$, Gert Verstraeten ${ }^{\mathrm{a}, \mathrm{b}}$, Hans Renssen ${ }^{\mathrm{c}}$, Bastiaan Notebaert ${ }^{\mathrm{a}, \mathrm{d}}$, \\ Koen D'Haen ${ }^{\mathrm{a}}$, Johan Bakker ${ }^{\mathrm{a}, \mathrm{b}}$ \\ ${ }^{a}$ KU Leuven, Division of Geography \& Tourism, Department of Earth and Environmental Sciences, Celestijnenlaan 200E, Box 2409, B-3001 Leuven, Belgium \\ ${ }^{b}$ KU Leuven, Center for Archaeological Sciences, Celestijnenlaan 200E, Box 2408, B-3001 Leuven, Belgium \\ c VU University Amsterdam, Department of Earth Sciences, Faculty of Earth and Life Sciences, NL-1081HV Amsterdam, The Netherlands \\ ${ }^{\mathrm{d}}$ Research Foundation Flanders - FWO, Egmontstraat 5, B-1000 Brussels, Belgium
}

\section{A R T I C L E I N F O}

\section{Article history:}

Received 15 October 2015

Received in revised form 18 July 2016

Accepted 13 August 2016

Available online 16 September 2016

\section{Keywords:}

Geomorphic modeling

Soil depletion

Crop yield

Human impact

Land use change

Climate

\begin{abstract}
A B S T R A C T
Many hillslopes in the limestone dominated Taurus Mountain Range (SW Turkey) are characterized by severely depleted soils, while a significant amount of sediment is being stored in the valley bottoms. The same holds true for the $11.4 \mathrm{~km}^{2}$ endorheic Gravgaz basin in the vicinity of the Hellenistic-Roman city of Sagalassos in SW Turkey. Previous palaeo-environmental research in this basin already yielded both detailed sedimentological and palynological information on sedimentation in the valley bottom and vegetation changes that took place during the last several millennia. An adapted WATEM/SEDEM geomorphic model version was used to simulate the impact of the observed changes in vegetation cover, climate and hillslope soil properties on hillslope soil erosion and valley bottom sediment deposition over the last 4000 years. The calibrated WATEM/SEDEM model is able to reconstruct the temporal changes of sedimentation in the valley bottom reasonably well. To simulate the impact of historic soil erosion on crop productivity a simple crop yield model was coupled to the reconstructed soil thickness maps. The main outcomes are that soil erosion was mainly driven by deforestation and hence anthropogenic activity, but the resulting soil erosion did not cause a complete collapse of crop yields. On the contrary, we were able to quantify that the sediment accumulation in the lower lying valley bottoms compensated at least a part of the loss in crop yield from the hillslopes: potential crop yield value changed from $2.80 \mathrm{t} \mathrm{ha}^{-1} \mathrm{a}^{-1}$ before widespread deforestation to $2.58 \mathrm{t} \mathrm{ha}^{-1} \mathrm{a}^{-1}$ during Roman-Imperial times and $2.19 \mathrm{t} \mathrm{ha}^{-1} \mathrm{a}^{-1}$ at present. These model approaches are tools that allow us to quantify human impact in the past, going beyond traditional qualitative descriptions, which will ultimately lead to a better understanding of human-environment interactions in the past.
\end{abstract} (c) 2016 Elsevier B.V. All rights reserved.

\section{Introduction}

Humans have impacted their environment throughout history, especially since the introduction of widespread agriculture and the associated forest logging activities. Several studies pointed towards dramatic increases in rates of erosion and sedimentation following deforestation (Notebaert and Verstraeten, 2010; Montgomery, 2007; Dearing. and Jones, 2003; Dotterweich, 2013). Geoarchaeological studies have increasingly been focusing on sedimentary archives, linking events of soil erosion to archaeological, climatic or vegetation records, and ultimately relating the interplay between society and the environment to the decline of civilizations through processes such as overexploitation of the soil (Hughes and Thirgood, 1982; Van Andel et al., 1990; Bintliff, 2002; Beach et al., 2006). Such research topics, however, are of a complex nature and not easily resolved. In the first place, links between

\footnotetext{
* Corresponding author.

E-mail address: maarten.vanloo@kuleuven.be (M. Van Loo).
}

environmental factors and the geomorphic system are not necessarily accepted by scholars, leading to discussion of the relative importance of environmental driving forces (Butzer, 2005). Moreover, chronologies of sediment archives and records of driving forces are often not sufficiently detailed (Verstraeten, 2009). Additionally, synchronicity between environmental change and geomorphic system response does not necessarily imply a cause-effect relationship (Dusar et al., 2011; Vandenberghe, 2012), and vice-versa, the catchment can buffer geomorphic system response inducing a time lag between environmental change and the geomorphic system, hiding the cause and effect relationship (Trimble, 1999). The resilience of societies has also increasingly received attention since studies show that ancient societies were able to cope with a changing environment, or found ways to sustain at least a part of their material culture and social heritage (Schwartz and Nichols, 2006; McAnany and Yoffee, 2010; Butzer, 2012; Widlok et al., 2012). Given the complexity of these systems, modeling approaches can provide alternatives or be complementary with quantitative field data to come to a deeper understanding of human-environment 
interactions in the past (Verstraeten, 2014). A combination of sedimentary analysis and landscape evolution modeling already proved to be a viable solution to unravel the impact of human and natural induced driving forces on hillslope soil erosion and sediment redistribution over a Holocene time scale in Western and Central European environments (de Moor and Verstraeten, 2008; Ward et al., 2009; Notebaert et al., 2011).

Two major approaches have been used to model past landscape evolution: dynamic models and scenario-based models. Dynamic landscape evolution models (e.g. Coulthard, 2001; Peeters et al., 2006; Buis et al., 2010) simulate erosion and deposition over a number of consequent time steps. The WatemLt model (Peeters et al., 2006), for example, calculates back in time the effect of soil erosion processes and related sediment redistribution to assess the impact of changing climate and land cover. Other examples of dynamic models focus on different processes like mass movement, creep and reworking of alluvium, and allow interaction between neighboring cells (e.g. CAESAR: Coulthard et al., 1997; Baartman et al., 2013). However, models using average erosion rates such as WatemLt (Peeters et al., 2006, 2008) and more event-based models like CAESAR (Coulthard et al., 1997) yield comparable hillslope cross-sections over a Holocene time scale (Hancock et al., 2010). The alternative, scenario-based model type has also produced good results using scenarios of past land use and climate, without changing topography over time (e.g. Notebaert et al., 2011). Firstly, keeping topography constant through time has the advantage of avoiding numerical instability (e.g. Peeters et al., 2006; Temme et al., 2006); errors are aggregated over larger spatial units instead of accumulated on single grid cells. Secondly, input data with a low accuracy and precision, like past land use reconstructions, do not have to be provided continuously over time (Notebaert et al., 2011). The main disadvantage is the steady-state approach. Although the impact of changes in land use and climate can be incorporated in such model approaches (e.g. Notebaert et al., 2011), this is less evident for the dynamic nature of topography and soil properties. Peeters et al. (2006) did include changing topography, however, the computational challenges are large, certainly when applying the model to larger catchments and longer timescales. Typically landscape evolution models do include changing topography over time, but when applied on generated and abstract landscapes, they do not allow model validation (Coulthard, 2001). However the increasing computational powers allow more real-world model validation (Hancock et al., 2010).

What is mostly lacking, however, is the dynamic nature of the soil. Incorporating dynamic soils in landscape evolution models is seen as the way forward in earth surface modeling (Minasny et al., 2015). Large errors may be made when using the present-day state of the soils to model past geomorphic response to environmental change. This is especially the case in the Eastern Mediterranean, where present-day soils on hillslopes tend to be shallow, which is argued by many scholars to be the result of human-induced erosion following the first intense exploitations and forest clearings (Van Andel et al., 1986; Lowdermilk, 1953). The human-induced erosion hypothesis by Van Andel et al. contrasts with the climate hypothesis in the classic work of Vita-Finzi (1969) on sedimentation in Mediterranean valleys. Although subsequent studies (e.g. Bintliff, 2002; Butzer and Harris, 2007) pointed out that a combination of natural and anthropogenic factors could explain the variability in erosion and sedimentation, this has never been properly assessed through combination of field data and numerical modeling approaches in the Eastern Mediterranean.

For the Mediterranean region it was also hypothesized that soil erosion following the cultivation of land degraded the landscape to such an extent that it caused a crisis in ancient societies (Greece: Van Andel et al., 1990, Rome: Hughes and Thirgood, 1982). However, it has also been argued by Van Andel et al. (1986) for the Argolid, Greece, that the eroded material ended up in the wide valley bottoms thereby creating extensive areas of fertile land that were much easier to cultivate. Thus, it is hypothesized that hillslope soil erosion actually had an important and not necessarily exclusively negative impact on ancient civilizations through accumulation of soil in the central valleys. A modeling study of changing soil depths in space and time can be a first step to assess the effect of soil erosion on potential crop yields in the past. Many studies already aimed to quantify the impact of soil erosion on crop productivity. A good review of experimental data that explored the relation between soil erosion and crop productivity for a range of environments in Europe is provided by Bakker et al. (2005). Data show that crop yield is reduced by $4 \%$ for each $10 \mathrm{~cm}$ of soil lost. However, only considering studies in the Mediterranean, soil thickness seems to have a much stronger control on crop yield (i.e. Kosmas et al., 2001). Lee and Cruse (2015) also show that the relationship between soil thickness and crop yield is influenced by the amount of rainfall. Given the specific water balance in Mediterranean soils, the role of soil thickness in maintaining sustainable yields will probably be important as it serves as a way to buffer water in its hydrological cycle.

In this paper, we first aim to assess to which extent the depletion of soil profiles and the accumulation of sediment in valley bottoms is a consequence of natural or anthropogenic factors, or a combination of both. We applied a geomorphic erosion and sediment transport model that is adapted to take into account the dynamic properties of soil profiles following erosion and deposition processes in combination with an extensive field dataset on late-Holocene colluviation for a small basin in SW Turkey. Secondly, using the soil modeling as a starting point, a quantitative assessment of crop yield will open up the debate what role soil thickness could have played in sustaining ancient societies.

\section{Material and methods}

\subsection{Study area}

For this study an $11.4 \mathrm{~km}^{2}$ endoreic catchment in the south-west Turkish Taurus Mountain Range was selected. The Gravgaz study area $\left(37^{\circ} 35^{\prime} \mathrm{N}, 30^{\circ} 24^{\prime} \mathrm{E}\right)$ is part of the territory of the Hellenistic-Roman city of Sagalassos (Waelkens and Poblome, 1993; Paulissen et al., 1993; Waelkens et al., 1999). Its topography (Fig. 1) is dominated by a wide valley ( $17.5 \%$ of the total catchment area), at present filled with colluvial deposits around a marshy area $\left(1 \mathrm{~km}^{2}\right)$ in the valley centre at an altitude of $1220 \mathrm{~m}$ a.s.l. Present day climatic data are summarized in Fig. 2. Winters in the territory of Sagalassos are cold and wet, while summers are hot and dry (Paulissen et al., 1993). Annual precipitation reaches up to $600 \mathrm{~mm}$ with most precipitation occurring during winter, which can be in the form of snow. Annual temperature averages around $12{ }^{\circ} \mathrm{C}$. The valley is surrounded by limestone hills (60\%) up to $1590 \mathrm{~m}$ a.s.l. At several locations on the lower slopes, conglomerate (12\%) and ophiolite (10.5\%) are present (Fig. 1), as evidenced by extensive field surveys (Dirix, 2010). The central marsh area is partially drained through a karstic sinkhole at its eastern edge, but sediment export from the basin is assumed to be insignificant (Six et al., 2008). The colluvial fill of the valley bottom has been intensively studied by Six et al. (2008) and a detailed analysis of the temporal variation in sediment storage in the Gravgaz valley bottom is provided by Dusar et al. (2012). The 33 radiocarbon data retrieved from the 12 sediment cores allowed to establish a detailed chronology of sediment deposition in the valley bottom. Their results are used in this study to calibrate the geomorphic model. From the observed sediment storage, the average hillslope erosion rate $\left(E_{\mathrm{avg}}, \mathrm{mm} \mathrm{a}^{-1}\right)$ was calculated as follows (Dusar et al., 2012):

$\mathrm{E}_{\mathrm{avg}}=\frac{\mathrm{S}_{\mathrm{m}}}{\mathrm{A}_{\mathrm{tot}}-\mathrm{A}_{\mathrm{dep}}} \times \frac{1}{\mathrm{BD}_{\mathrm{avg}}}$

where $S_{m}$ is the annual mass of sediment stored within the depositional zone in the Gravgaz valley ( $\mathrm{a}^{-1}$ ); $A_{\text {tot }}$ is the total catchment area (ha); $\mathrm{A}_{\text {dep }}$ is the depositional area (ha); $\mathrm{BD}_{\text {avg }}$ is the average bulk density of the hillslope topsoil (1.35 t/m³ , analogous to Hoffmann et al., 2008). 


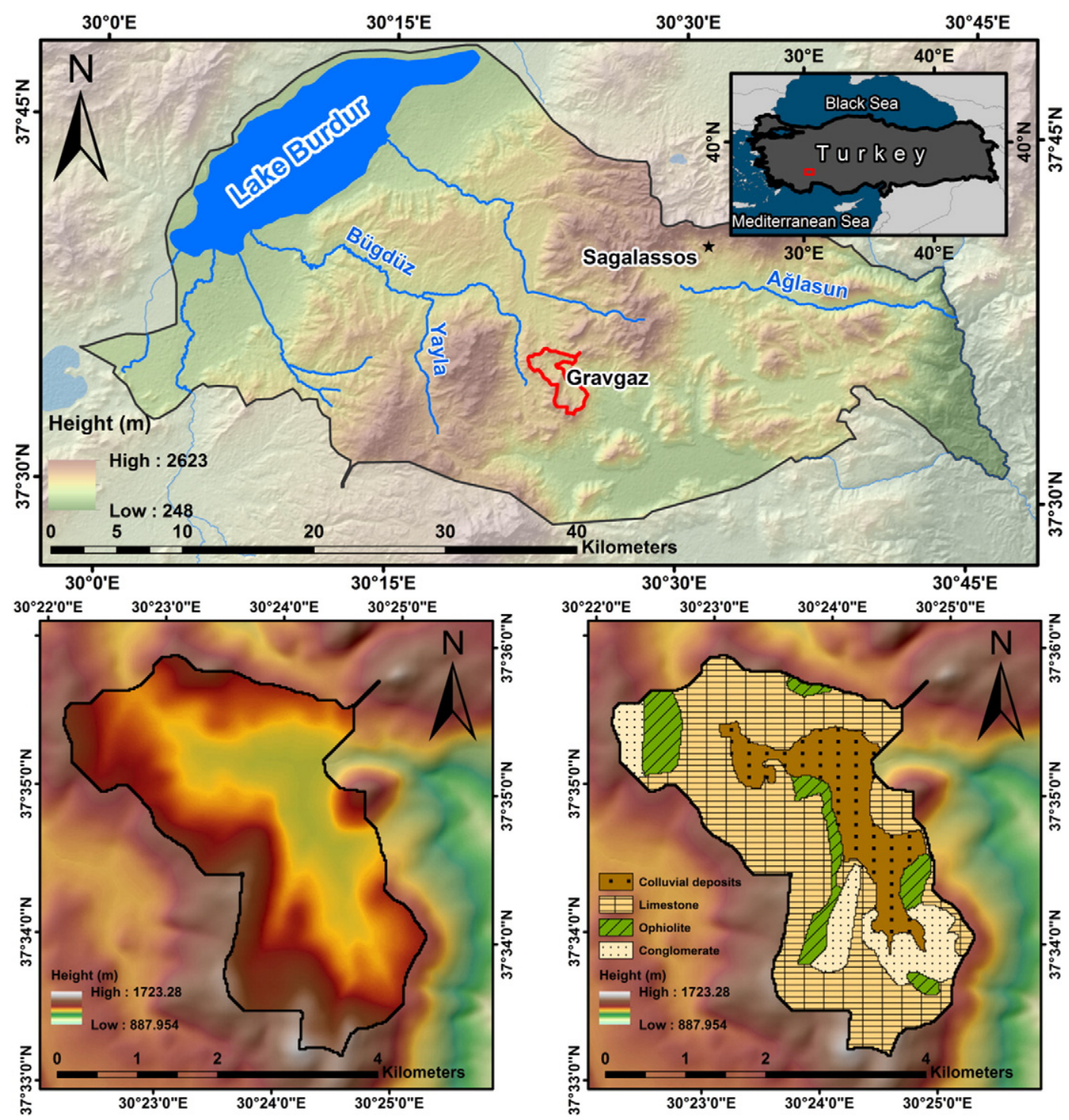

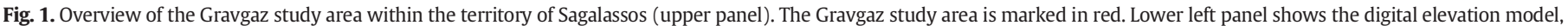
lower right the four main lithological units.

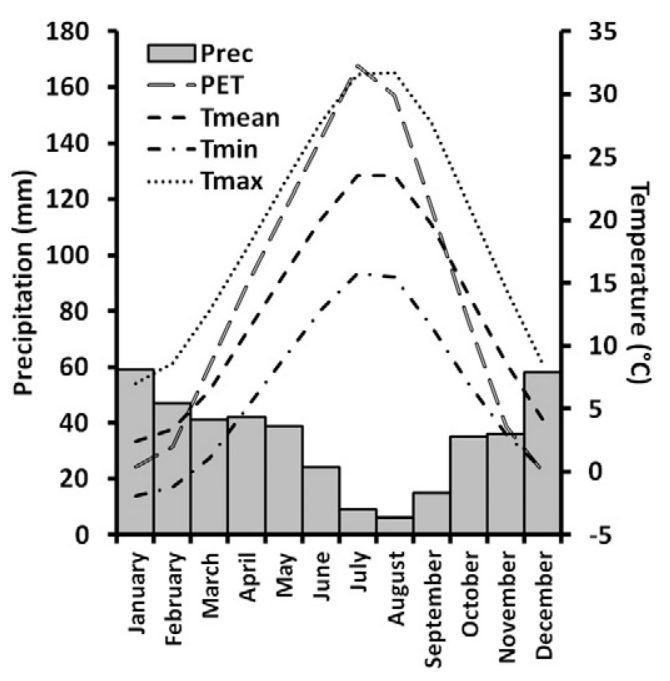

Fig. 2. Present day climatogram of the study area (Grieser et al., 2006).
The valley bottom sedimentation curve is shown in Fig. 3, taking into account the uncertainties on storage calculations as well as radiocarbon dating through Monte Carlo modeling (Dusar et al., 2012). During the period from $4000 \mathrm{BCE}$ to about $860 \mathrm{BCE}$ sedimentation rates were low with just $<400 \mathrm{t} \mathrm{a}^{-1}$ of hillslope-derived sediment that was delivered to the valley bottom. Following Eq. (1), this corresponds to a net average catchment-wide hillslope erosion rate of $0.03 \mathrm{~mm} \mathrm{a}^{-1}$. From 860 BCE onwards sediment delivery increased gradually until 530 BCE, when sediment delivery peaked at $2675 \mathrm{t} \mathrm{a}^{-1}$ or an equivalent net average hillslope erosion rate of $0.21 \mathrm{~mm} \mathrm{a}^{-1}$. These high sedimentation rates were sustained until about $300 \mathrm{BCE}$, after which sediment delivery decreased to average values of $1533 \mathrm{t} \mathrm{a}^{-1}$ during the next 2300 years. However, the sediment delivery during this recent period still varied significantly between $1300 \mathrm{t} \mathrm{a}^{-1}$ and $1920 \mathrm{t} \mathrm{a}^{-1}$.

\subsection{Model description}

The geomorphic model selected for this study is the WATEM/SEDEM model, a spatially distributed soil erosion and sediment delivery model. Detailed descriptions of the model are provided by Van Oost et al. 


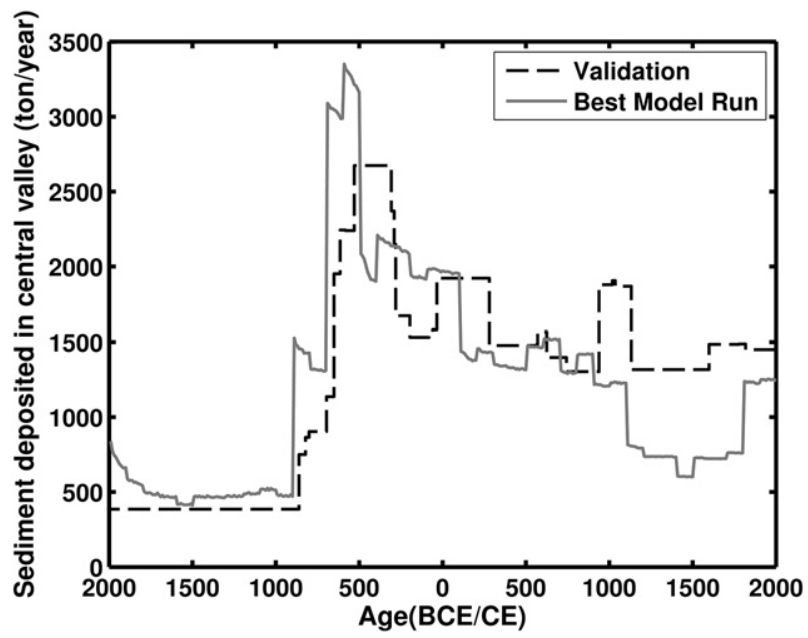

Fig. 3. Modeled sediment deposition in the central valley of the Gravgaz catchment (solid grey line) versus the temporal variation in sediment deposition over the last 4000 years obtained from the radiocarbon dated $(n=33)$ coring dataset $(n=12)$ used for calibration (dashed black line) (Dusar et al., 2012).

(2000); Van Rompaey et al. (2001a) and Verstraeten et al. (2002). The original WATEM/SEDEM is in essence a non-dynamic, raster-based model existing of two main components. The first component calculates soil erosion using an adapted RUSLE approach for 2D landscapes:

\section{$\mathrm{E}=\mathrm{RKLSCP}$}

where $\mathrm{E}$ is the mean annual soil loss (ton $\left.\mathrm{ha}^{-1} \mathrm{a}^{-1}\right)$; $\mathrm{R}$ is the rainfall erosivity factor (MJ mm ha-1 $\mathrm{h}^{-1} \mathrm{a}^{-1}$ ); $\mathrm{K}$ is the soil erodibility factor (ton $\mathrm{h} \mathrm{MJ}^{-1} \mathrm{~mm}^{-1}$ ); LS is the two-dimensional slope-length factor to account for flow convergence (Desmet and Govers, 1995); C the crop management factor; and $\mathrm{P}$ the erosion control practice factor.

The second component consists of the routing of the eroded sediment downslope using a single-flow algorithm where each grid cell is evaluated for sediment deposition based on its transport capacity (TC):

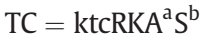

where A is the upslope contributing area (ha), $\mathrm{S}$ the slope factor of the LS. The exponents $a$ and $b$ for area and slope typically range between 1 and 2 (Prosser and Rustomji, 2001). ktc is the transport capacity coefficient which reflects the amount of sediment that can be transported downslope related to sub-grid cell vegetation effects (Verstraeten et al., 2007). TC equation (Eq. (3)) ensures that erosion rates and sediment transport are calculated independently, which is different from earlier WATEM/SEDEM applications in loess areas in central Belgium (e.g. Van Rompaey et al., 2001) where TC is proportional to the erosion rate E. Having sediment transport being proportional to the same topographic parameters used for erosion can lead to intense sedimentation especially in areas with flow convergence on lower hillslopes, while in such areas often gully incision is observed. This approach (Eq. (3)) was tested with success in the Mediterranean environment of the upland Australian Murrumbidgee River catchment (Verstraeten et al., 2007) as wel as in other (sub-)Mediterranean catchments in Spain and Slovenia (de Vente et al., 2008; Keesstra et al., 2009; Alatorre et al., 2010). The value of $a$ was set at 1 instead of 1.4 to reflect the infiltration of water flow into dry Mediterranean soils as suggested by e.g. Rustomji and Prosser (2001), causing a slower increase in transport capacity with increasing slope length. Tillage erosion was not accounted for in the model since most of the area is too steep or remote to be tilled. Some tillage might have occurred, be it using animals, and hence having a lower impact on erosion.

\subsection{Model adaptation}

To study Late Holocene sediment dynamics in the Gravgaz catchment, the original WATEM/SEDEM model had to be adapted since the model normally produces a single annual output, while in this study a 4000 year time period is considered. Peeters et al. (2006) developed the WatemLt model from the original WATEM/SEDEM, which could be run over the entire Holocene. The topography of the study area is adapted over time following erosion and deposition, but this causes significant numerical problems (Peeters, 2007). In the Eastern Mediterranean Gravgaz catchment, marked by much steeper slopes, rocky outcrops and a generally less smooth topography, such a backwardscalculating approach is even more problematic. Furthermore, annual changes in topography through soil erosion are relatively less important compared to the study of Peeters (2007) since topography is already rather pronounced.

Therefore, instead of adapting the topography, a soil thickness map is introduced that evolves over time with ongoing erosion and deposition. At the start of the model simulation (2000 BCE), the entire catchment is assumed to be covered by a soil mantle with a total mass equal to that of the sediments deposited in the central marsh from 2000 BCE onwards, based on calculations of Dusar et al. (2012). Each grid cell was assigned a soil thickness proportional to the curvature of that grid cell using a linear relationship following the findings of Heimsath et al. (1999). Maximum soil thickness was limited to $100 \mathrm{~cm}$, and the slope of the linear relationship between curvature and soil was calibrated in such way that total mass of the soil thickness map matched the total amount of sediments found in the central marsh. A random scatter of -15 to $15 \mathrm{~cm}$ was added to the soil thickness map to account for the irregular topography of the limestone bedrock. The soil thickness map was generated based on two assumptions (1) the sediments deposited in the Gravgaz valley bottom over the last several millennia originated from the hillslopes rather than developed in situ (e.g. through weathering); and (2) hillslope soil erosion prior to the late Holocene was very limited, which is plausible because of the mostly dense forest cover in the region (e.g. Roberts et al., 2001; Vermoere et al., 2002). In addition, we observed that almost no soil cover remains on the hillslopes today.

The model is run for the hillslopes surrounding the Gravgaz valley bottom. Sediment export from the hillslopes is assumed to be deposited in the central marsh, which is left out of the model domain. Every 10 years the adapted WATEM/SEDEM produces soil erosion and soil thickness maps, the remaining 9 years in between each calculation are assumed to have the same annual soil loss as the first year of the 10 year sequence.

Based on initial model run results, sediment deposition rates were also capped at $3 \mathrm{~mm} \mathrm{a}^{-1}$ to avoid excessive sedimentation at a single grid cell at the transition of steep ( $>25 \%$ ) hillslopes to relatively gentle concave footslopes (slope $<5 \%$ ). This way no grid cell will accumulate $>12 \mathrm{~m}$ of soil from 2000 BCE onwards, which is in line with the maximal deposition observed in the central valley. Previous WATEM/SEDEM did not yet tackle the problem of such sharp topographic boundaries.

\subsection{Model input parameters}

The RUSLE R-factor is derived from the rainfall data obtained from a climate reconstruction by Renssen et al. (2009). The ECBilt-CLIOVECODE model was used to simulate monthly rainfall and temperature data over the past 9000 year whereby atmosphere, sea ice, ocean and vegetation are coupled. The model compares well with proxy records over large parts of the northern hemisphere, although there is no specific validation for SW-Turkey.

The coarse $5.6^{\circ}$ by $5.6^{\circ}$ ECBilt-CLIO-VECODE resolution needed to be downscaled in order to get relevant climate data for the Gravgaz catchment. This was done by comparing our data with the CRU TS 1.2 dataset (Mitchell et al., 2003), which combines monthly climate observations 
for roughly the last century on a resolution of $10^{\prime}$ by $10^{\prime}$ in Europe. The ECBilt-CLIO-VECODE output data for the last century was resampled to the $10^{\prime}$ by $10^{\prime}$ resolution and the deviations from the CRU TS 1.2 dataset were calculated and applied to the resampled ECBilt-CLIO-VECODE output. We assume that this downscaling factor remained the same the past 4000 years, and that the downscaled climate data within the $10^{\prime}$ by $10^{\prime}$ grid cell also applies to Gravgaz, ignoring further topographic effects on precipitation at an even finer scale within the $10^{\prime}$ by $10^{\prime}$ grid cell. Details on the downscaling approach can be found in Bouwer et al. (2004) and Ward et al. (2007). The RUSLE R-factor is then calculated using the downscaled monthly rainfall estimations and the following formulas, calibrated for the Seyhan River basin in southern Turkey (Irvem et al., 2007):

$\mathrm{R}=0.1215 \times \mathrm{F}^{2.2421}$

with F the modified Fournier index, calculated as follows (Arnoldus, 1977):

$\mathrm{F}=\frac{\sum_{\mathrm{i}-1}^{12} \mathrm{P}_{\mathrm{i}}^{2}}{\mathrm{P}}$

where $P_{i}$ is the monthly rainfall $(\mathrm{mm})$ and $P$ the yearly rainfall $(\mathrm{mm})$. This allows the temporal variability of monthly precipitation to affect the rainfall erosivity. The distribution of rainfall extremes however, are not taken into account to calculate the R-factor. As the palaeoclimate model provides monthly rainfall data over 100 -year time periods, WATEM/SEDEM is also provided with an R-factor value per 100-year time periods.

The past land cover maps for the study area (Fig. 4) are reconstructed based on extensive palynological data obtained from the central valley bottom (Vermoere et al., 2000, 2002; Bakker et al., 2011). The pollen study results, mainly the arboreal pollen (AP) percentage, the presence of disturbance indicators such as Artemisia and the anthropogenic indicators like cereals, are used to estimate the land cover over the last 4000 years. However, the pollen data do not provide quantitative information concerning land use, but rather indicate the timing of important land use changes. This temporal information is of crucial importance for the hypothetical land use reconstructions used in the geomorphic model. For simplicity, vegetation is generalized into a non-degraded land cover category (e.g. Oak or Pine forest), and a degraded land cover category (e.g. Quercus coccifera shrubland, grassland and agricultural land; Kaniewski et al., 2007). The RUSLE C-factors for the land cover categories were set at 0.0005 for non-degraded land cover, in line with Mediterranean fynbos vegetation in South Africa (Van Rompaey et al., 2001b); for degraded land cover, the C-factor was set at 0.25 , similar to arable land in Western Europe, since good estimates for C-factors in the region are lacking (Irvem et al., 2007). Although these estimates may not correspond to the actual C-factor values in the study area, getting their relative proportion rights is considered more important than knowing their exact values. For six sub-periods, the proportion of both degraded and non-degraded land cover categories is estimated based on the pollen records. A MATLAB script allocates degraded land cover to the lowest slopes present in the catchment until the proportion prescribed by the pollen record is met. Some degree of randomness is kept in the allocation process to refrain from creating sharply defined land cover maps. This leaves the undegraded land cover to occur preferably on the steeper slopes, as these were generally less accessible and hence less likely to be cultivated or used for grazing. Since no real quantitative data concerning land use categories are available, these maps are a rough estimate of land use.

In addition, the relation between soil thickness and soil erodibility (RUSLE K-factor) has to be specified in order to capture the important dynamic property of Mediterranean soils, i.e. the reduction of soil erodibility with increasing stone cover as the soil erodes. (Fig. 5). In the Gravgaz study area four main lithological units are present: limestone, ophiolite, conglomerate and colluvial deposits. The soil erodibility (Kfactor) of stone-free topsoil is assumed to be 0.035 ton h MJ $\mathrm{MJ}^{-1} \mathrm{~mm}^{-1}$, in line with so-called brown soils in the region (Irvem et al., 2007). Furthermore, it is assumed that for a stone-free topsoil, bedrock is at least one meter below the surface. For limestone, stone cover increases progressively with decreasing height above bedrock, which results in a K-factor profile as shown in Fig. 5. The K-factor, dependent on soil profile depth, is calculated as follows (Box, 1981):

$\mathrm{K}=\mathrm{K}_{\text {text }} \times \exp (-0.0278 \times \mathrm{St})$

where $K_{\text {text }}$ is the original $\mathrm{K}$-factor without reduction from stone cover and $\mathrm{St}$ is the mass of stones in the topsoil expressed as a percentage of total mass of the topsoil.
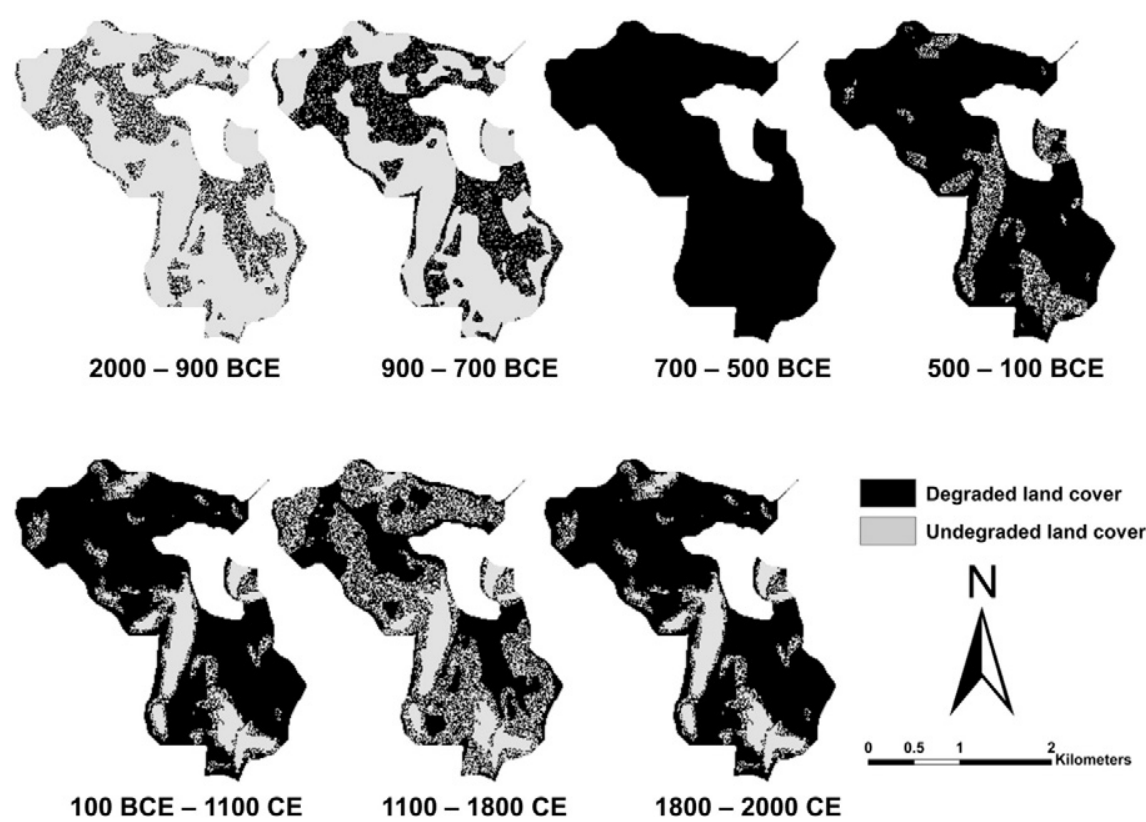

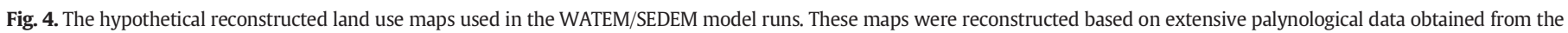
central valley bottom (Vermoere et al., 2000, 2002; Bakker et al., 2011). Degraded land cover was preferentially allocated to grid cells with a low slope. 


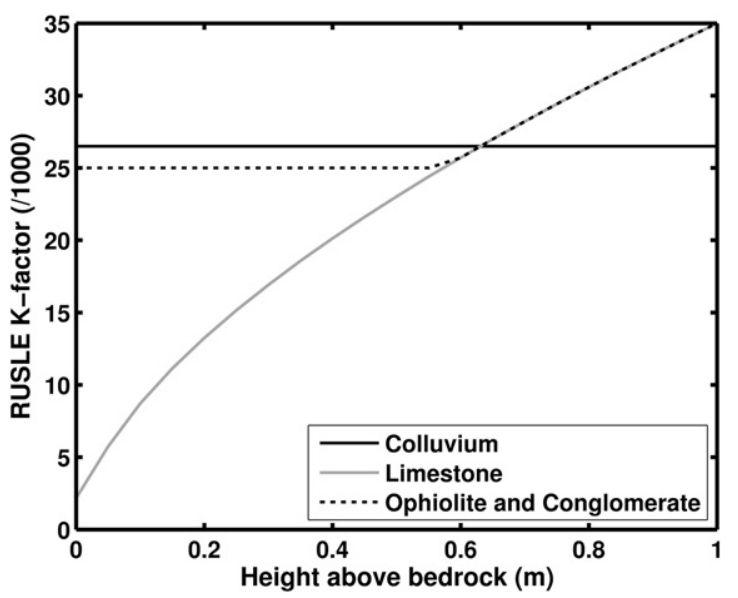

Fig. 5. K-factor evolution with decreasing soil depth for the lithologies present in the Gravgaz catchment: colluvium (black), limestone (grey) and ophiolite/conglomerate (black dotted line).

For ophiolite and conglomerate, initially the same K-factor profile is assumed, but since bedrock for these lithologies is much more erodible, the K-factor at bedrock level was set at 0.025 . For colluvial deposits, which in the study area typically contain $10-15 \%$ stones, the K-factor is set to 0.0265 , which corresponds to a stone cover of $12 \%$, and this value does not change with decreasing soil depth. Soil formation is not considered in the model, since soil formation from bedrock weathering is generally very slow in the region and may not attain values $>8 \mathrm{~mm}$ per $10 \mathrm{ka}$ (Yaalon, 1997).

Finally, the LS factor in the model is calculated from a DEM. A digitized contour map with a contour spacing of $20 \mathrm{~m}$ was processed in ArcGIS to construct a DEM with a resolution of $20 \mathrm{~m}$. The DEM was filtered with a 5 by 5 grid cell mean-filter to remove some artifacts from the contour to DEM conversion process in the more topographically pronounced areas, which would otherwise obstruct a correct sediment routing.

\subsection{Model calibration and evaluation}

The only parameter in the adapted WATEM/SEDEM model that has to be calibrated is the ktc-value in Eq. (3), for both land cover categories. In total 81 calibration runs were performed whereby ktc values for nondegraded land cover were varied between 0 and 2 and for degraded land cover between 1 and 3, both with intervals of 0.25 .

Model performance was evaluated using the Relative Root Mean Squared Error (RRMSE, Eq. (7)) and Model Efficiency (ME, Eq. (8)):

RRMSE $=\frac{\sqrt{\frac{1}{n} \sum_{i=1}^{n}\left(O_{i}-P_{i}\right)^{2}}}{\frac{1}{n} \sum_{i=1}^{n} o_{i}}$

$\mathrm{ME}=\frac{\sum_{\mathrm{i}=1}^{\mathrm{n}}\left(\mathrm{O}_{\mathrm{i}}-\mathrm{P}_{\mathrm{i}}\right)^{2}}{\sum_{\mathrm{i}=1}^{\mathrm{n}}\left(\mathrm{O}_{\mathrm{i}}-\mathrm{O}_{\text {mean }}\right)^{2}}$

with $\mathrm{O}_{\mathrm{i}}$ the observed value or sediment delivery to the central valley, $\mathrm{P}_{\mathrm{i}}$ the predicted value or modeled sediment delivery to the central valley and $\mathrm{O}_{\text {mean }}$ the average observed value. Both ME and RRMSE are calculated using averaging both observations and model outputs over a 100 year time period. Using this calibration approach we aim to predict the temporal evolution of the sediment delivery correctly which is important when evaluating the relative impact of the various driving forces, which also vary temporarily.
Because of the importance of stone cover on soil erodibility (RUSLE K-factor) in mountainous Mediterranean catchments, an additional dataset $(n=285)$ of topsoil stone content on the hillslopes was collected, in order to assess the present-day state of the hillslopes. These point data were collected by photographing rectangular $1 \times 1 \mathrm{~m}$ grids with a $10 \times 10 \mathrm{~cm}$ subgrid, which were laid down at random locations in the catchment. For each point also lithology, slope and curvature were observed, along with present-day vegetation cover. Topsoil stone content was estimated by counting the number of subgrid crossings covering a stone. The adapted WATEM/SEDEM model calculates the soil thickness above bedrock at the grid cell level for each time step, and the relationship between soil thickness, RUSLE K-factor and stone cover is known. Therefore, the modeled topsoil stone content was compared with the present-day observed stone content, yielding additional information on model performance.

\subsection{Crop yield modeling}

To assess the effect of soil thickness on crop yield the AquaCrop model was used (Raes et al., 2009). AquaCrop is a simple water-driven crop yield model that can be used on a variety of soil and climate conditions after local validation. Although other more mechanistic crop yield models allow to understand the plant-environment functioning, they are also very input-demanding. AquaCrop allows to model crop yields with a relatively small amount of input parameters, and since data on past climate, soil and plant functioning is hard to obtain, the AquaCrop model is preferred over more demanding models in this study. The model uses canopy ground cover to calculate transpiration, which on its turn is multiplied with the harvest index (HI) to come to crop yield. Soil fertility, water and temperature stresses can reduce crop yield through the crop's transpiration (Steduto et al., 2009). A soil thickness-crop yield relationship for winter barley was created by running the AquaCrop for multiple soil depths at the Gravgaz catchment using present day climate conditions. The standard AquaCrop model parameters for winter barley were used to construct the soil thickness-crop yield relationship. Catchment wide average crop yields can then be calculated by multiplying the obtained soil thickness-crop yield relationship with the modeled soil thickness maps.

\section{Results}

\subsection{Model calibration and evaluation}

Modeled sediment export to the central valley for the 81 calibration runs are shown in Fig. 6A. Their respective ME and RRMSE values are shown in Fig. 6B, C and D. ME and RRMSE values are highly sensitive to the ktc-values for degraded land cover, contrastingly, the ktc-values for undegraded land cover barely influence ME and RRMSE. A ktc value for degraded land cover of 2 and undegraded land cover of 1 yielded best results for ME and RRMSE (Fig. 3). Although with 0.45 and 0.39 optimal ME and RRMSE respectively are rather low, the bestfit model run underestimates the total valley sediment storage by only $4 \%$.

The model run with optimal ktc-values shows that initially, before 900 BCE, the Modeled sediment delivery to the Gravgaz valley bottom is low, but around 900 BCE sediment delivery increases $>3$-fold after a first land clearance phase, and even goes up to six times the amount of 900 BCE at the peak clearance phase during the Iron Age. These high sedimentation rates are sustained for two centuries, but from about 500 BCE onwards sediment delivery drops a first time, and again around $100 \mathrm{CE}$ to a level equal to that of the first clearance phase. Around $1000 \mathrm{CE}$ sedimentation rates drop again and more or less stabilize until $1800 \mathrm{CE}$ at an average of $790 \mathrm{t} \mathrm{a}^{-1}$, a slightly higher level compared to the first phase. Sedimentation rates rise a final time at $1800 \mathrm{CE}$. The main temporal patterns of sediment delivery are reconstructed relatively well by the model, although sediment delivery 

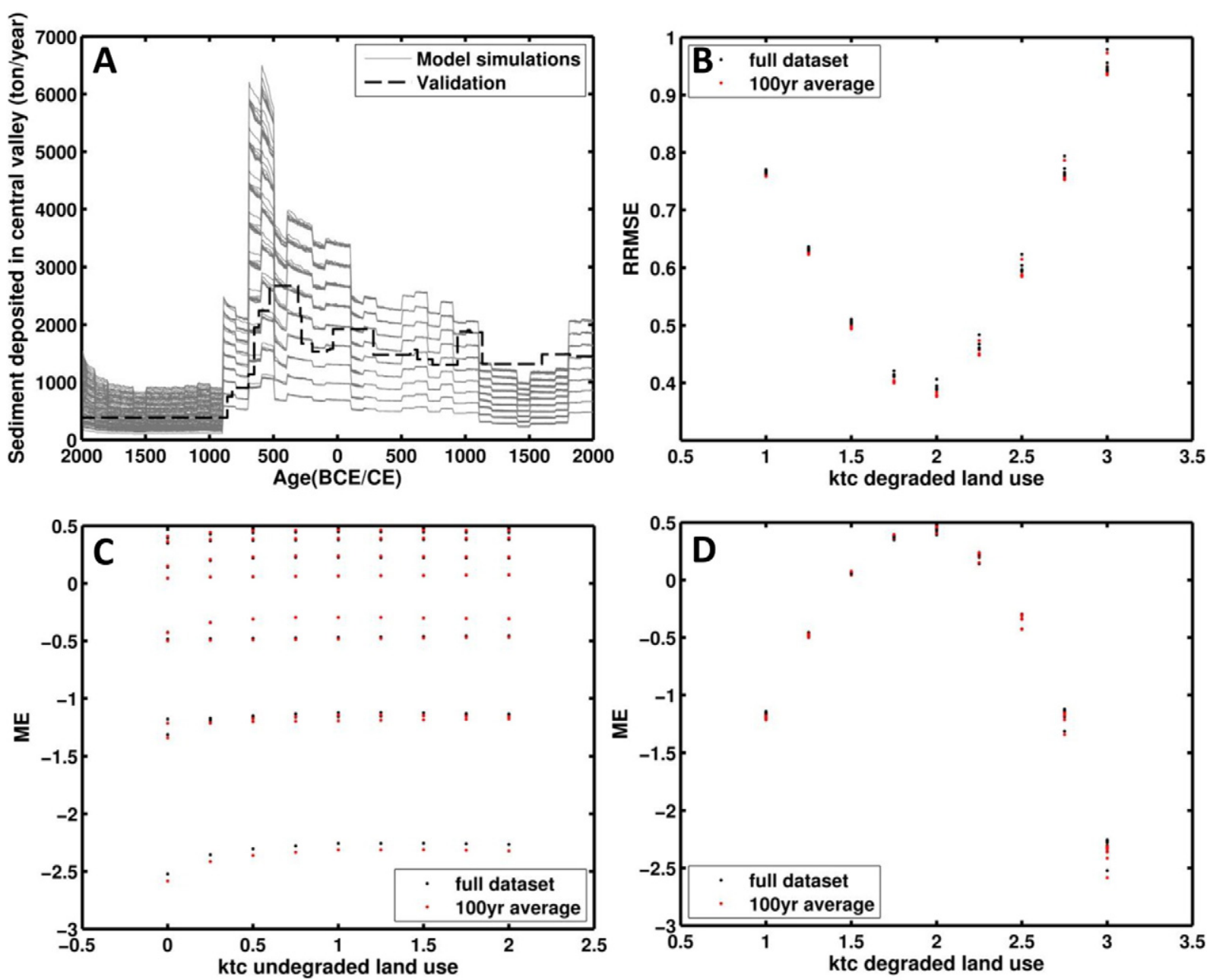

Fig. 6. Modeled sediment export to the central valley (ton/year) for the 81 calibration runs (A), and their respective ME and RRMSE (B, C and D).

between 1100 and $1800 \mathrm{CE}$ is too low compared to the field based estimated sediment delivery. Nevertheless, this model run allows for further analysis to assess the impact of the various driving forces controlling sediment export in the Gravgaz study area.

From the soil thickness map, also the initial and final topsoil stone content can be derived, which can then be compared with the field observations Fig. 7. The modeled present-day stone content (Fig. 7) represents the measured present day stone content relatively well. Some discrepancies between the model and observation do remain however.

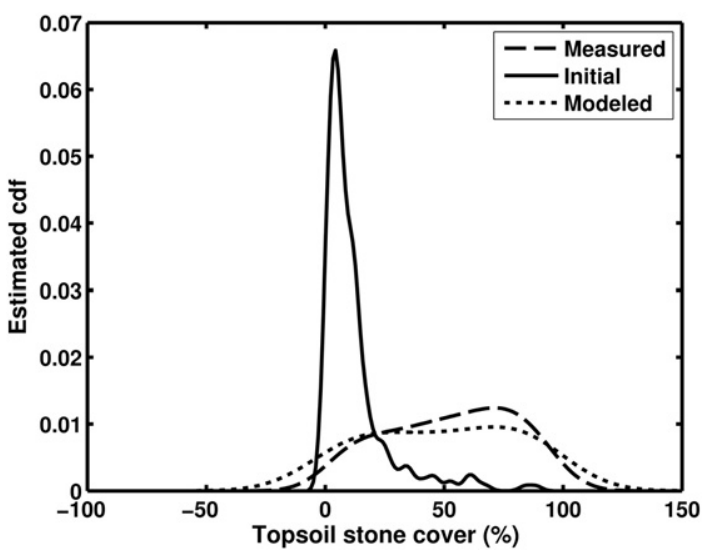

Fig. 7. Estimated cdf of initial topsoil stone cover (\%) (solid line) and both modeled (dashed line) and measured (dotted line) final (2000 CE) topsoil stone cover (\%).

\subsection{Spatial patterns of soil depths}

Fig. 8 shows the spatial pattern of soil erosion and deposition integrated over the entire 4000 year study time period. The net deposition in the small colluvial valleys to the south and northwest of the central valley bottom is obvious. The difference in erosion values between ophiolite and conglomerate areas on the one hand and limestone areas on the other hand is clear. The former lithologies are marked by a higher erodibility (RUSLE K-factor), while in limestone terrain, once the soil is depleted only very erosion-resistant bedrock remains.

Soil thickness also changes significantly. Soil thickness is higher in the central valleys, whereas the hillslopes are stripped from their initial soil mantle (Fig. 9). Fig. 10(A) shows the evolution of 3 soil thickness classes (blue: $>60 \mathrm{~cm}$, green: $30-60 \mathrm{~cm}$, red: $<30 \mathrm{~cm}$ ). Initially, soils not exceeding $30 \mathrm{~cm}$ are limited in spatial extent, whereas at $2000 \mathrm{BCE}$ around $70 \%$ of the catchment is covered with soils of this category. Most of these soils are located on the hillslopes, in contrary to the deepest soils, which are progressively moved towards the valley areas over the course of the simulation. At the end of the simulation, around $50 \%$ of the soils exceeding $60 \mathrm{~cm}$ are located in the valley areas.

\subsection{Crop yield modeling}

Eq. 9 shows the constructed relationship between soil thickness and crop yield obtained in AquaCrop.

$\mathrm{CY}=2.841\left(1-\left(\exp ^{(-0.055 * \mathrm{ST})}\right)\right)$ 


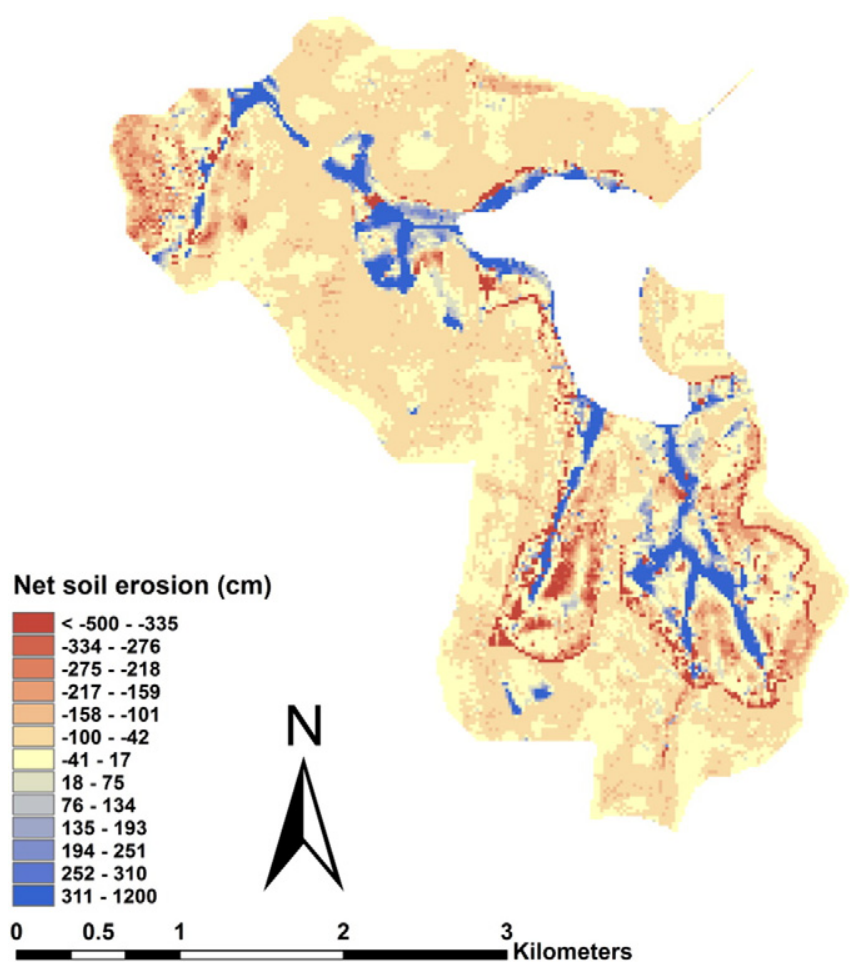

Fig. 8. Total soil erosion and deposition integrated over the 4000 years model time (cm).

where CY is crop yield ( $\mathrm{t} \mathrm{ha} \mathrm{a}^{-1} \mathrm{a}^{-1}$ ) and ST is soil thickness ( $\left.\mathrm{m}\right)$. Crop yield greatly increases up to a soil thickness of $70 \mathrm{~cm}$ (Fig. 10, B). After this threshold, crop yield stagnates around $2.85 \mathrm{tha}^{-1} \mathrm{a}^{-1}$. Assuming the CY - ST relationship remained the same over the course of the considered time period, catchment wide average crop yields decrease with $56 \%$ going from $2.50 \mathrm{t} \mathrm{ha}^{-1} \mathrm{a}^{-1}$ in 2000 BCE to $1.11 \mathrm{t} \mathrm{ha}^{-1} \mathrm{a}^{-1}$ in 2000 CE (Fig. 11, left panel, solid black line). Fig. 12. shows the average crop yields for each slope class and soil thickness category. Only considering the valley area, the average crop yield decreases with only $22 \%$, from $2.80 \mathrm{t} \mathrm{ha}^{-1} \mathrm{a}^{-1}$ in $2000 \mathrm{BCE}$ to $2.18 \mathrm{t} \mathrm{ha}^{-1} \mathrm{a}^{-1}$ in $2000 \mathrm{CE}$. This compared to a $64 \%$ drop only considering the hillslope areas, from $2.44 \mathrm{t} \mathrm{ha}^{-1} \mathrm{a}^{-1}$ in $2000 \mathrm{BCE}$ to $0.88 \mathrm{tha}^{-1} \mathrm{a}^{-1}$ in 2000 CE. The average crop yield in the valley area only considering the degraded land cover category decreases with $22 \%$ from $2.80 \mathrm{tha}^{-1} \mathrm{a}^{-1}$ to $2.19 \mathrm{t} \mathrm{ha}^{-1} \mathrm{a}^{-1}$. Average crop yield in the hillslope area only considering the degraded land cover category decreases with $63 \%$ from $2.47 \mathrm{tha}^{-1} \mathrm{a}^{-1}$ in $2000 \mathrm{BCE}$ to $0.91 \mathrm{tha}^{-1} \mathrm{a}^{-1}$ in $2000 \mathrm{CE}$.

\section{Discussion}

\subsection{Model calibration and evaluation}

The model was calibrated based on the minimization of difference between modeled and observed mean valley deposition for 100 year periods. It could be argued that the model should be calibrated based on the total sediment deposition in the valley bottom over the entire model time span, not taking into account the temporal patterns, since this will introduce more uncertainties. Still, the first calibration procedure was chosen because of two reasons: firstly, it is assumed that sufficient temporal information was available to constrain the temporal build-up of the sediment deposits in the valley bottom (Dusar et al., 2012). Secondly, the data concerning driving factors (climate and land cover) were also available on a temporal basis, which allowed for the identification of their relative importance.

The problem that still remains though is that only one catchment is studied, making the calibration of ktc susceptible to autocorrelation. Indeed, if catchments are calibrated separately there is a possibility that for each catchment a unique optimal ktc will be found, which will result in good model performance, however, only for that one catchment. To really test the model's strength, other catchments should also be included in the calibration procedure. This requires a more extensive dataset of sediment chronologies though.

To tackle the problem of autocorrelation, an alternative calibration method can be used, whereby $50 \%$ of the dataset is used to calibrate the model, and the remaining $50 \%$ is used for validation. Repeating this random selection 10,000 times results in a large range of calibrated ktc values for which the corresponding ME could be calculated based on
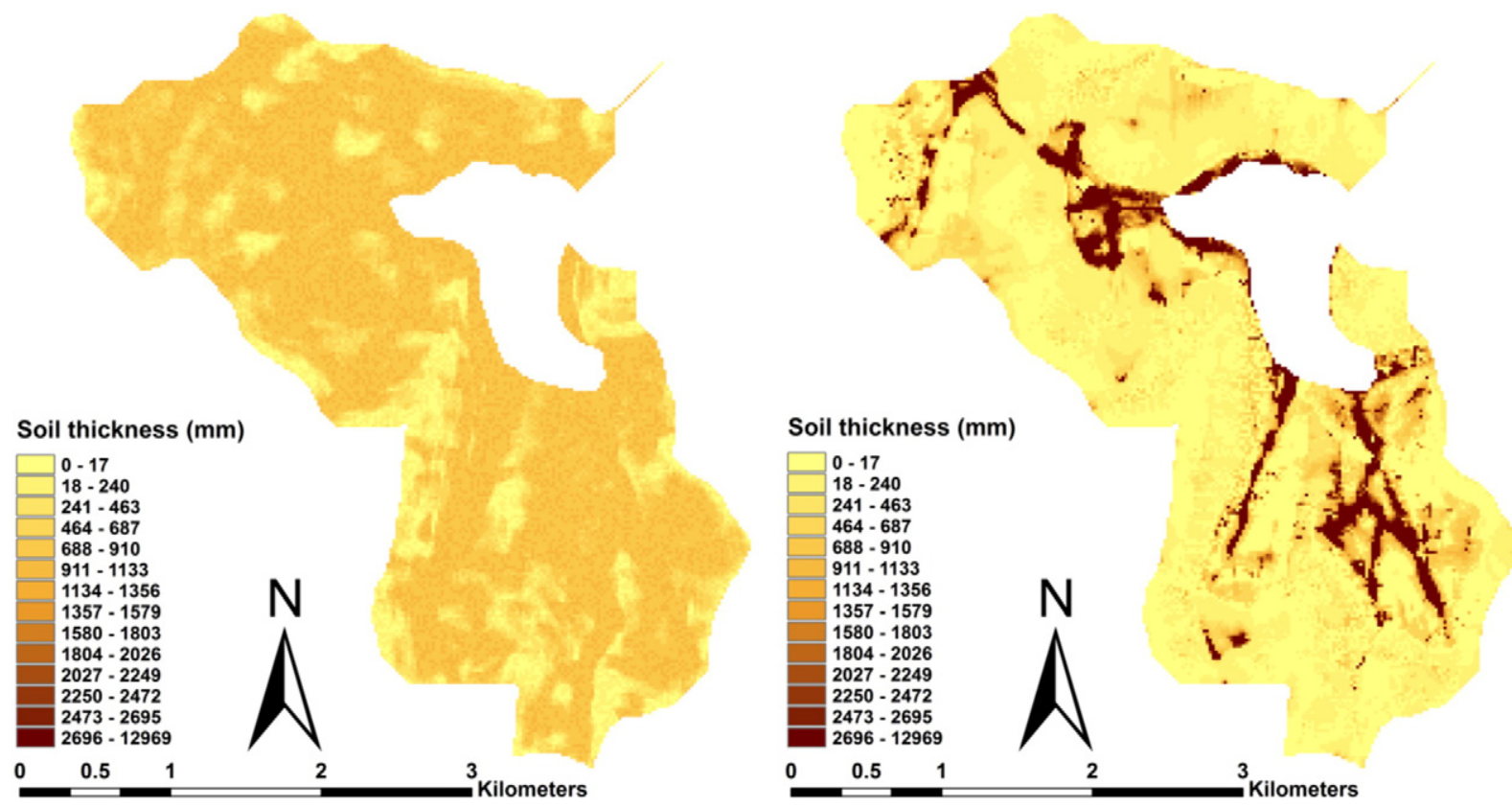

Fig. 9. Initial (left) and final (right) modeled Soil Thickness map (mm). 

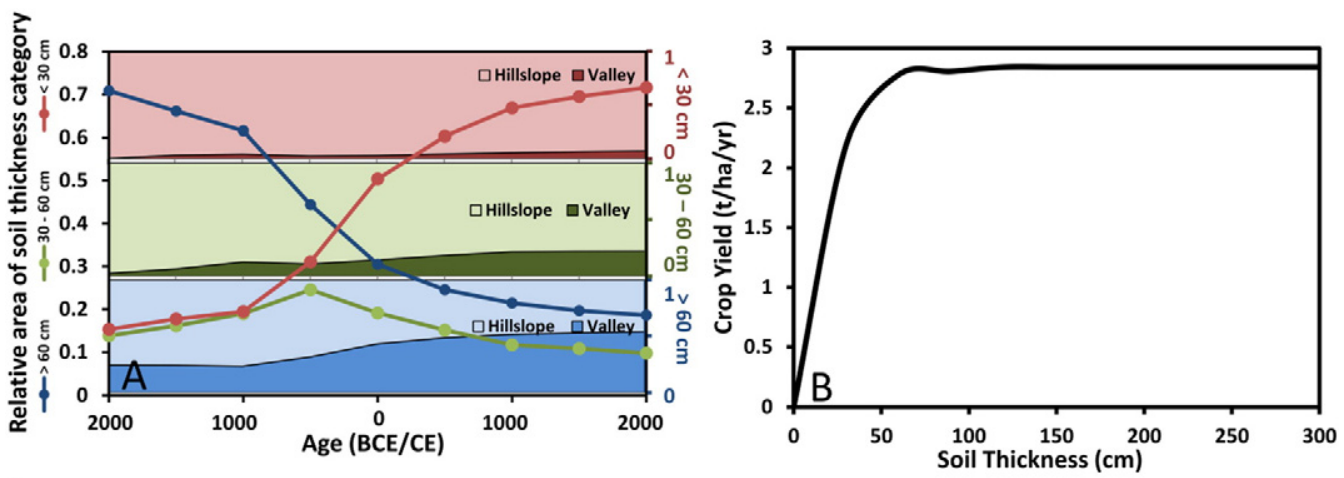

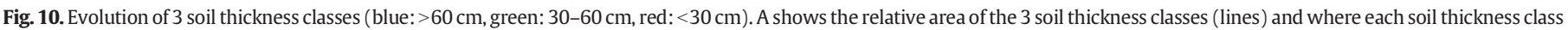

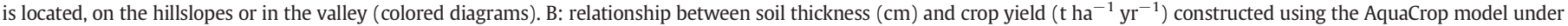
present day conditions in Gravgaz for winter barley.
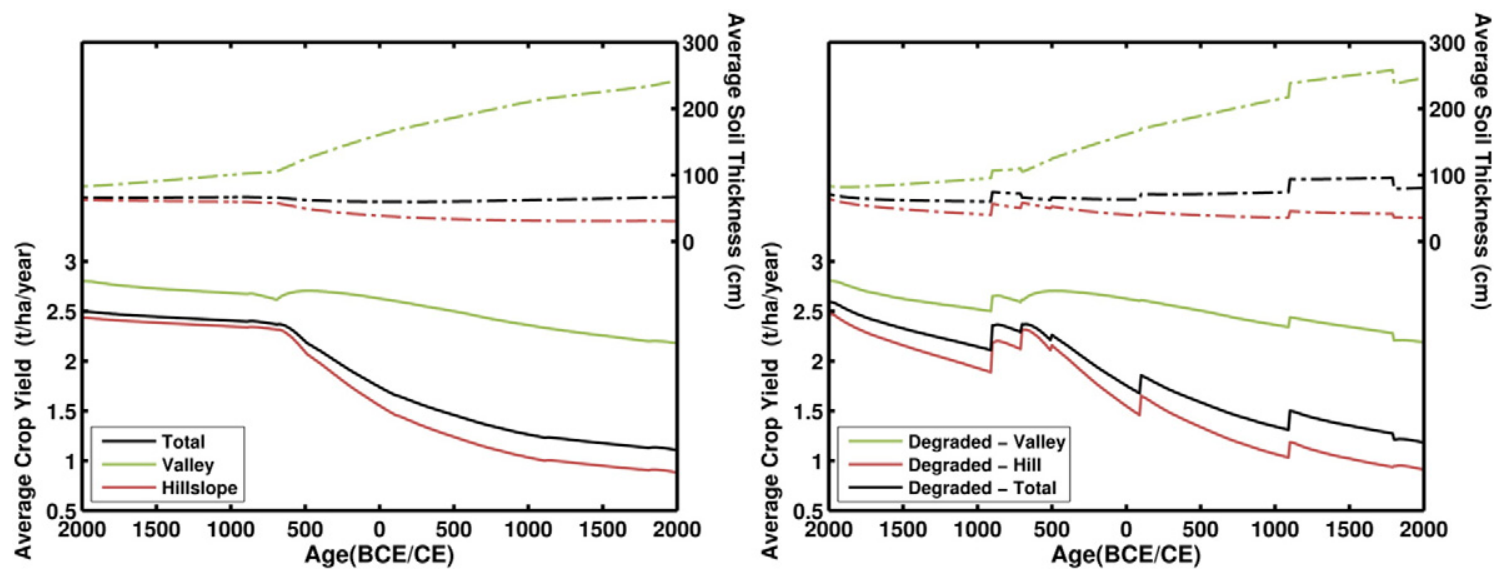

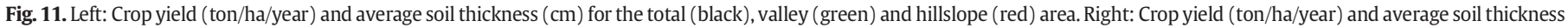
$(\mathrm{cm})$ for the total degraded (black), degraded valley (green) and degraded hillslope (red) area.

the $50 \%$ remaining data points not used for calibration. Fig. 13 (left panel) shows the estimated cumulative distribution function (cdf) of the ME values, Fig. 13 (right panel) shows the corresponding estimated cdf for ktc-values with a ME higher than 0.5 . The 10,000 calibration runs

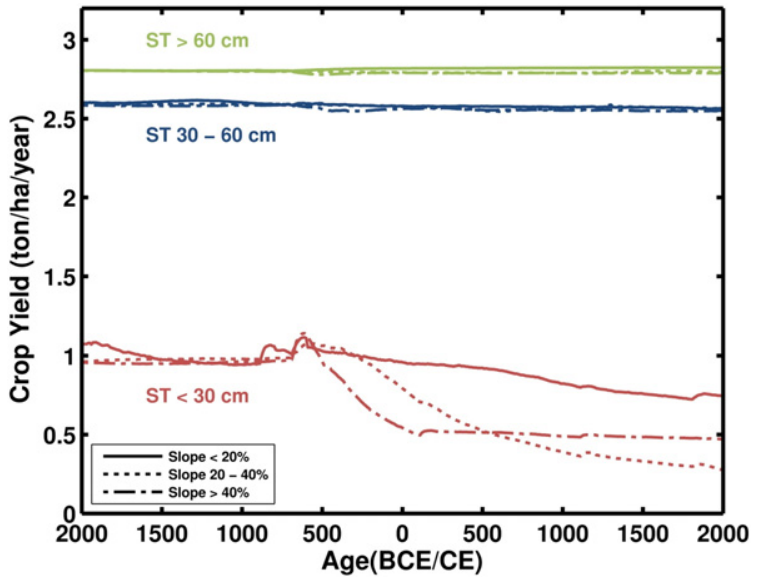

Fig. 12. Crop yield (ton/ha/year) for each soil thickness (cm) category and slope (\%) category. result in a mean $\mathrm{ME}$ of 0.49 , with a standard deviation of \pm 0.16 . A large part of the calibration runs thus result in a similar ME as obtained by using the full dataset to calibrate the model. The ktc-values with a ME higher than 0.5 range between 1.65 and 2.48. Using these values as a low and high limit of acceptable ktc values, we can see what the influence is of these extreme values on soil erosion and crop yield modeling. Fig. 14 shows results of model simulation results using the original ktcvalue for degraded land cover, as well as the low and high estimates of 1.65 and 2.48 indicated by the shaded area. Although there is a large effect on the sediment export to the central valley, soil thickness isn't affected as much using a ktc-value for degraded land cover of 1.65 and 2.48. As a result, crop yield stays relatively constant using a wide range of calibrated ktc-values for the degraded land cover. The results thus show that even if ktc-values wouldn't be optimally calibrated, our finding on the effect of soil erosion on crop yield stay unchanged.

Stone cover was used as an additional validation dataset. Discrepancies between modeled and measured stone cover will partly be due to the different resolution at which both stone covers are obtained: The stone cover was measured in the field using a $1 \mathrm{~m}^{2}$ square, while the DEM grid cell size is $20 \times 20 \mathrm{~m}$. Nevertheless, the stone cover distribution does allow comparison between measurements and model results. These observations do suggest that the modeling approach is capable not only to predict the temporal pattern in sediment delivery correct but also the spatial variability of soil depletion. 

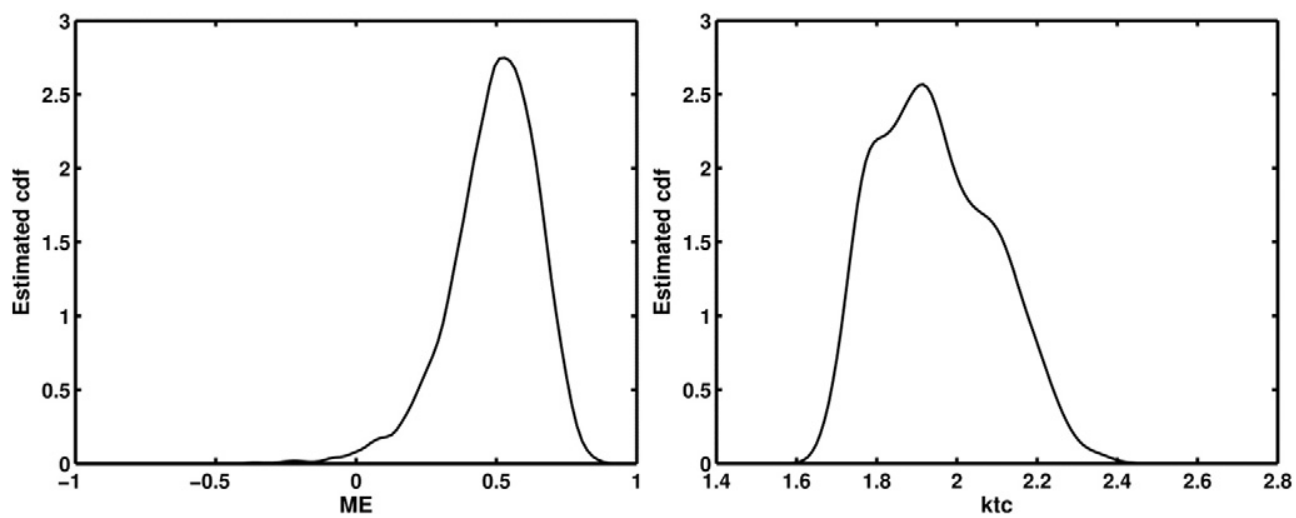

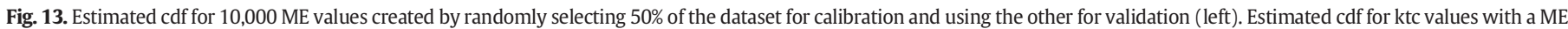
higher than 0.5 (right).

\subsection{Factors determining sediment fluxes}

A detailed analysis of the best-fit model run (Fig. 15) allows assessing the relative importance of the driving forces of the geomorphic system. By far, the influence of the landscape-wide land cover (RUSLE C-factor) seems to be the most important, as the valley sediment delivery (SD) curve closely follows the C-factor trend. Before $900 \mathrm{BCE}$, the vegetation is largely undisturbed (low C-factor), and sedimentation rates are low. From 900 BCE onwards, when the landscape is largely deforested and the C-factor rises with $97 \%$ from the initial low level, the sediment delivery towards the valley bottom increases by

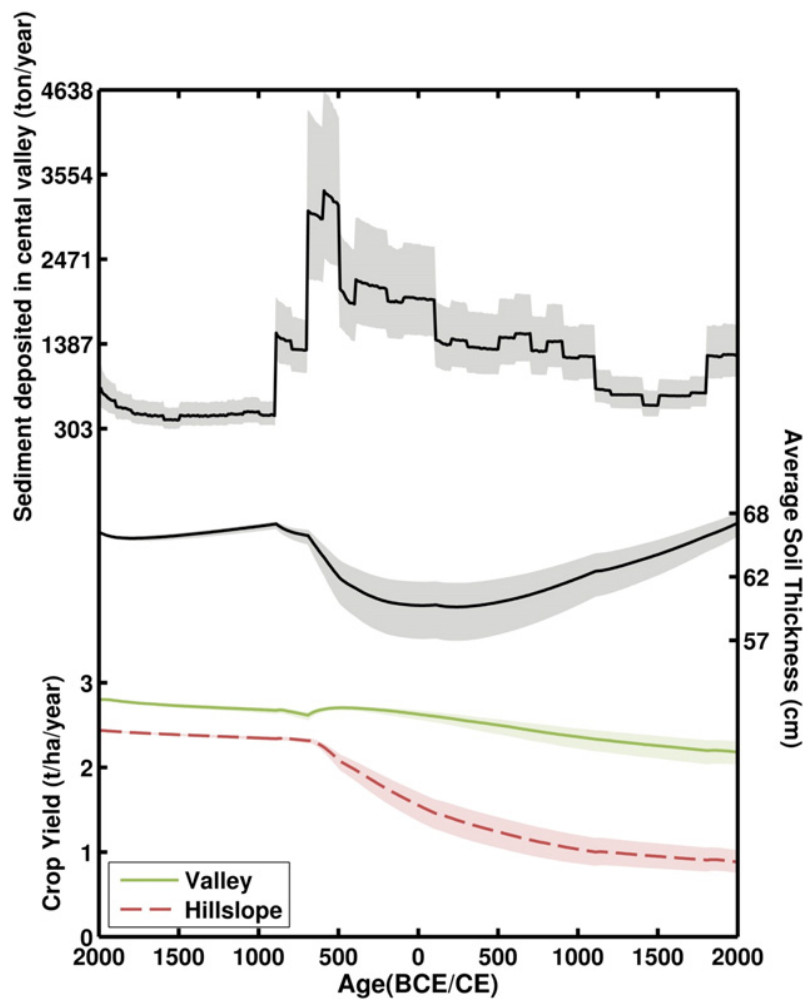

Fig. 14. Shaded areas show the range of model outcomes for sediment deposited in central valley (ton/year), average soil thickness $(\mathrm{cm})$ and crop yield $(\mathrm{t} / \mathrm{ha} / \mathrm{year})$ with a ME exceeding 0.5 . ME was calculated by randomly selecting $(n=10,000) 50 \%$ of the dataset for calibration and using the other for validation. Lines show the original model results calibrated and validated using the whole dataset. Despite ktc-values for degraded land cover varying between 1.65 and 2.48 , the effect on crop yield is rather small.
224\%. The 2nd land clearance peak between 700 and 500 BCE marks an increase in C-factor of $149 \%$ and a following increase in SD of $136 \%$. The landscape disturbance is sustained until $1100 \mathrm{CE}$, when the pollen diagrams indicate a reforestation of the area with Pine (Bakker et al., 2011). The landscape C-factor decreases by $25 \%$, and this leads to a decrease in SD by $34 \%$. While the general trend in SD is thus controlled by the $\mathrm{C}$-factor, the R-factor also clearly influences SD, although on a shorter timescale. Indeed, the square-wave-like pattern of the R-factor is also visible, superimposed over the C-factor controlled SD curve, though with a smaller absolute impact compared to the C-factor. The relative impact of the R-factor, however, is not negligible. Indeed, an increase of $7 \%$ and decrease of $5 \%$ in R-factor before widespread land clearance around $500 \mathrm{BCE}$ clearly results in a respective increase and decrease in SD of $12 \%$ and $15 \%$, the response thus being much higher than the impact. During the clearance phase, an increase in R-factor of $8 \%$ results in an increase in SD of 12\%. After soil depletion around 1500 CE, a decrease and increase of $12 \%$ in $\mathrm{R}$-factor results in a respective decrease and increase of $17 \%$ and $20 \%$ in SD. The effect of the K-factor is less visible on shorter timescales, however, its impact is important on longer timescales compared to the $\mathrm{C}$ and-R-factor. The effect of the K-factor can be seen more clearly during periods or more or less constant $C$ and $\mathrm{R}$, especially after major land clearance phases at 900 and 700 BCE. Here, SD drops strongly, following the curve of average catchment K-factor decrease. Between 900 and 800 BCE, K-factor drops with $1 \%$, resulting in a drop in SD of 6\%. Between 700 and 600 BCE, when K-

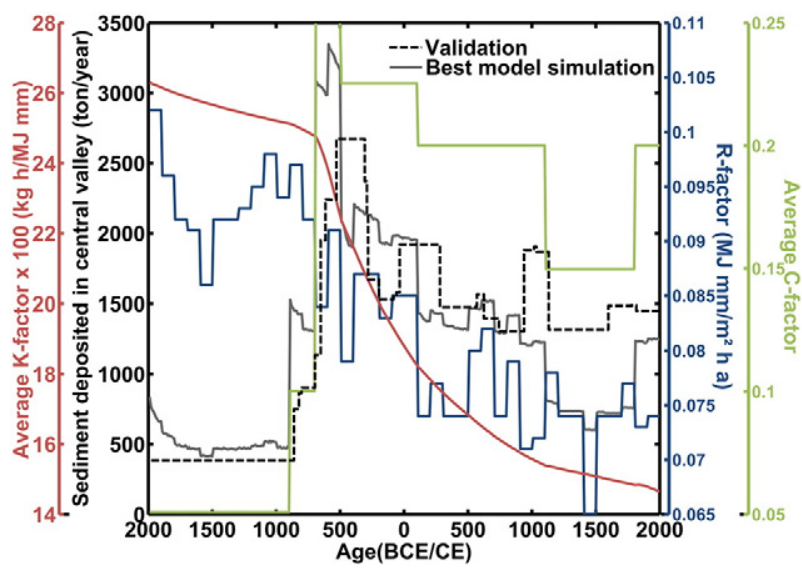

Fig. 15. Driving forces controlling sediment delivery to the central marsh: K-factor in red, $\mathrm{C}$-factor in green, R-factor in blue. Black dotted line shows the calibration curve, solid grey line shows the best model simulation. 

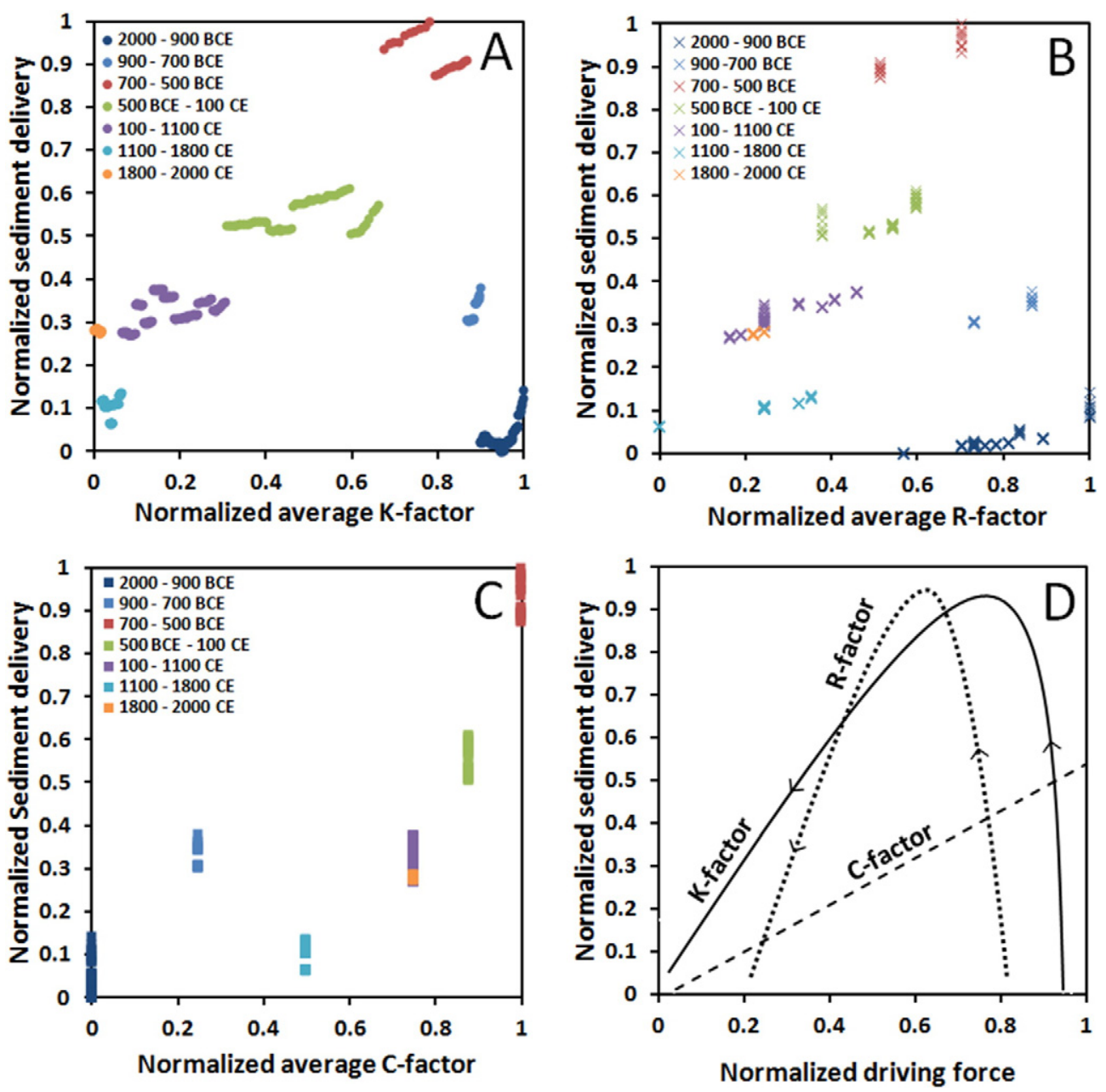

Fig. 16. A, B and C show the effect of driving forces on sediment delivery. Each plot normalized to facilitate comparison. D conceptually visualizes these effects.

factor decreases at its strongest rate of $4 \%$, SD drops with $3 \%$. Before widespread land clearance between 1000 and 900 BCE, a decrease in $\mathrm{K}$-factor of $1 \%$ results in a decrease in SD of $2 \%$. When soils are largely depleted from 500 CE onwards between 1200 and 1400 CE a decrease in K-factor of $1 \%$ results with a decrease in SD of only $1 \%$.

Fig. 16 visualizes these conclusions. SD was normalized with its minimum and maximum and each driving forces as well with its own minimum and maximum. Only the $\mathrm{C}$-factor shows the expected linear effect on SD. Indeed one would expect SD to increase linearly with K, R and Cfactor cf. Eq. (2), hereby assuming for simplicity that soil erosion and SD are linearly related. Periods between 100 and 1100 CE, 1100-1800 CE and 1800-2000 CE have a rather low SD for a rather high C-factor value. This shows the decrease of potential soil erosion after soil depletion or also how the landscape is less sensitive to its driving forces since larger C-factors are needed to achieve the same SD values before major land clearance. The $\mathrm{K}$ and $\mathrm{R}$-factor follow a more hyperbolic trend, although a linear relationship does emerge when only considering the time periods after land clearance has started. This illustrates the change in geomorphic functioning of the landscape. The overall scatter on Rfactor and the resulting overlap in SD values makes the R-factor a weaker predictor than the other two driving forces.

Comparing SD to the central marsh directly with driving forces can reveal some insights, although some effects will always be invisible since sediment routing and interplays between topography and driving forces upstream of the central valley cannot be properly assessed this way. However, from these observations we can conclude that the temporal variation in sediment storage in the Gravgaz valley bottom is largely determined by land cover changes, and hence that anthropogenic activity was the main driver behind environmental change.

\subsection{Importance of soil depletion}

Above findings on K-factor-SD forcing suggest that during the early phase of human occupation, when soil depth is still sufficient, it is not a limiting factor for controlling soil loss. However, once soil depth becomes too low, a critical threshold is crossed and a negative feedback between soil depth and erosion is established. In ancient times forest clearance and enhanced erosion rates led to rapid depletion of soils, especially on a limestone substrate. The importance of this soil depletion has been described in the Mediterranean, but also in other regions of the world (e.g. Hutchinson, 1969; McNeill, 1992; McNeill and Winiwarter, 2004; Beach et al., 2006). This soil depletion causes the present-day landscape to be much less erosion prone than the landscape during the first millennium BCE, which was also found both empirically and through modeling by e.g. Poesen et al. (1994) and Govers et al. (2006).

The adapted WATEM/SEDEM model does not only provide information on sediment delivery to the valley bottom, but also on sediment production and deposition at the grid cell level (Fig. 17). In comparison with the lithological map, it allows to calculate the importance of the different lithologies as sediment sources within the Gravgaz catchment. Specifically, we calculated netto erosion as well as average soil thickness for each lithology separately. For limestone areas, soil depletion and 


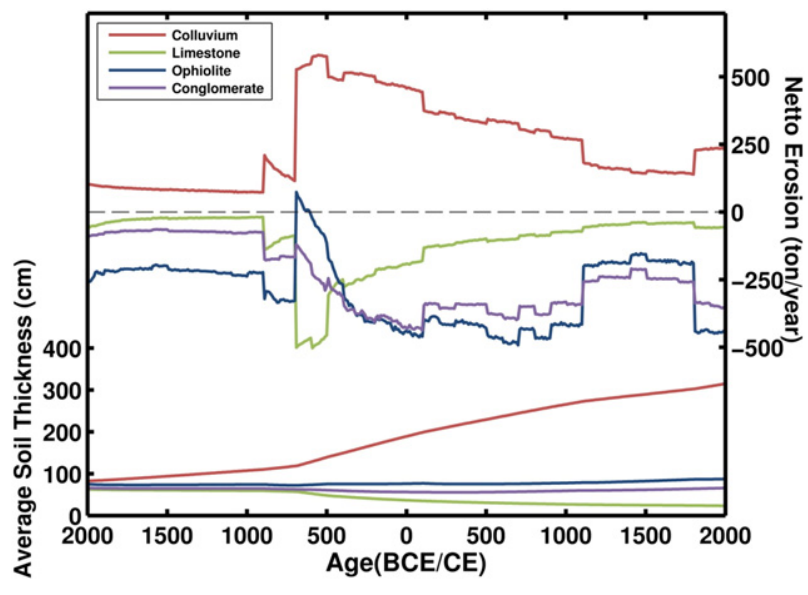

Fig. 17. Modeled netto erosion (ton/year) and average soil thickness (cm) per lithology.

resulting increase in stoniness results in a reduction of erosion in the from 700 BCE onwards, whereas ophiolite and conglomerate areas keep producing sediments throughout the model simulation. Furthermore, during this time period, a large portion of limestone area is converted back to the undegraded land cover category resulting in less material being transported towards to lower lying ophiolite and conglomerate areas, where still most grid cells are degraded. This results in a decrease of sediment supply over the ophiolite and conglomerate areas, making it possible for more material to be eroded over these lithologies.

Although the hillslopes are stripped from their soils, the morphology of the Gravgaz catchments allows for sediments to be stored in the valley bottoms, which in turn increases crop yield on these lower lying fields. Fig. 11 shows how the valley area is able to maintain average crop yields above $2.5 \mathrm{tha}^{-1} \mathrm{a}^{-1}$ in contrast to the hillslope area. Average soil thickness also increases in the valley area, again in contrast to the hillslope area. Calculated crop yield values should also be considered to be potential values. Indeed, not every single grid cell will have been cultivated in the past. Taking into account only the degraded land cover grid cells, a more realistic estimate of actual crop yield values can be obtained: potential crop yield value changes from $2.8 \mathrm{tha}^{-1} \mathrm{a}^{-1}$ before widespread deforestation to $2.58 \mathrm{t} \mathrm{ha}^{-1} \mathrm{a}^{-1}$ during Roman-Imperial times and $2.19 \mathrm{tha}^{-1} \mathrm{a}^{-1}$ at present. However, not all grid cells classified as degraded land cover were used for agriculture. For instance, steep slope sections are not favorable for cultivation, not only for the lower productivity values but also because of the physical challenges these slopes pose. Often these steeper slopes are used for extensive grazing practices. But since most steeper slopes are excluded in the valley area these figures should be able to show that the Roman-Imperial land clearances did not necessarily create completely degraded landscapes, and that still reasonably values of crop yield could be obtained in parts of the landscape. Hence these results suggest that the impact of soil erosion on crop yield and the sustainability of society was not always as dramatic as was often portrayed (Van Andel et al., 1990, Hughes and Thirgood, 1982). These findings, however, should not be extrapolated to other areas in the territory of ancient Sagalassos, however, since the landscape shows a varying degree of connectivity (D'Haen et al., 2013) which affects the potential to store sediments. To quantify the impact of soil erosion for a larger part of the territory of ancient Sagalassos, future analysis should include the diversity in landscape properties in the territory. Looking at the potential for agriculture on the hillslopes for degraded land cover grid cells, we see that average soil erosion during Roman-Imperial times is reduced to $1.5 \mathrm{tha}^{-1} \mathrm{a}^{-1}$. Agriculture at the hillslopes would probably have become increasingly difficult. Other locations in the territory largely consist of these kind of hillslope morphologies, suggesting a bigger impact of soil erosion on the sustainability of society.

Although the effect of climate, the different field management strategies, and the chemical properties of the soil are not yet included in the crop yield calculations these model simulations do suggest that the effects of human induced soil erosion in the past did not have an exclusively negative effect on crop yield: accumulation of soil in the valley bottoms induces a local crop yield rise, which partly compensates the loss on the hillslopes. Although there is still room for improvement, using this model approach we are able to quantify the effect of ancient soil erosion on crop yields, going further than qualitative descriptions made by Van Andel et al. (1986). Further studies should focus on validation of the crop yield modeling through both present day crop yield measurements as well as estimations of ancient crop yields (e.g. through nitrogen isotope compositions; Araus et al., 2014).

\subsection{Scope: soil erosion model improvements}

Although the model is able to simulate the main periods of human impact on the past, with a ME and RRMSE of 0.45 and 0.39 respectively, the model doesn't perform extremely well. Both input data and model complexity can be improved. The calculated R-factor only partly agrees with recent regional hydroclimate reconstructions (Dean et al., 2015), and the monthly rainfall extremes are not included in the R-factor calculation, which might lower model performance. The sharp drop in SD from 1100 until 1800 CE doesn't compare well with the more or less stable SD rates from the validation curve. Possibly the C-factor values for this period are set too low. Palynological studies do point out that landscape was less open during this time period (Bakker et al., 2011), but in reality the change could have been less drastic then the C-factor value now suggests. As mentioned above, the land cover proportions and their allocation are rough estimations derived from pollen data and simple assumption on land preferences in ancient times. Furthermore, the peak in SD between 1000 and 1100 CE in the validation curve is not reflected in the model. Bakker et al. (2013) record an increase in fire events for this period pointing out to a possible increase in agricultural activity. Fig. 18 (left) shows the modeled SD curve with the two above mentioned C-factor effects taken into account. Both ME and RRMSE are improved to respectively 0.66 and 0.30 . The peak in SD between 1000 and 1100 CE is not properly reflected by this model simulation, since the most degraded land cover grid cells added in this time period cover the already depleted limestone soils. Including more soil dynamics in the model can also lead to better model predictions. As an example, a changing landscape connectivity was introduced by changing the ktc-values throughout the model simulation. The modeled SD shown in Fig. 18 (right) was achieved by introducing a ktc-value for degraded land use of 1.6 which over time increases in a sigmoidal way, reaching 2.5 at the end of the model simulation. At the beginning of the simulation the lower ktc-value of 1.6 reflects a still relatively undisturbed vegetation type, allowing more sediments to be trapped at the sub-grid cell scale. Over time more disturbed vegetation types are introduced as the ktc-value increases towards 2.5 , reflecting an increased sediment connectivity. Pollen analyses indeed show us that not only the fraction of AP/NAP has changed due increased anthropogenic impact on the land, but also that the type of vegetation changed into variants of a more degraded nature (Bakker et al., 2011). This model setup is able to increase ME and RRMSE up to 0.64 and 0.31 respectively.

Although all alternative model scenarios do improve model performance, there is no real data available to validate these alternatives. A proper evaluation of different land cover scenarios and/or time-dependent ktc-values is only possible if more detailed chronologies on sediment properties and palaeo-vegetation exists for other sites. 

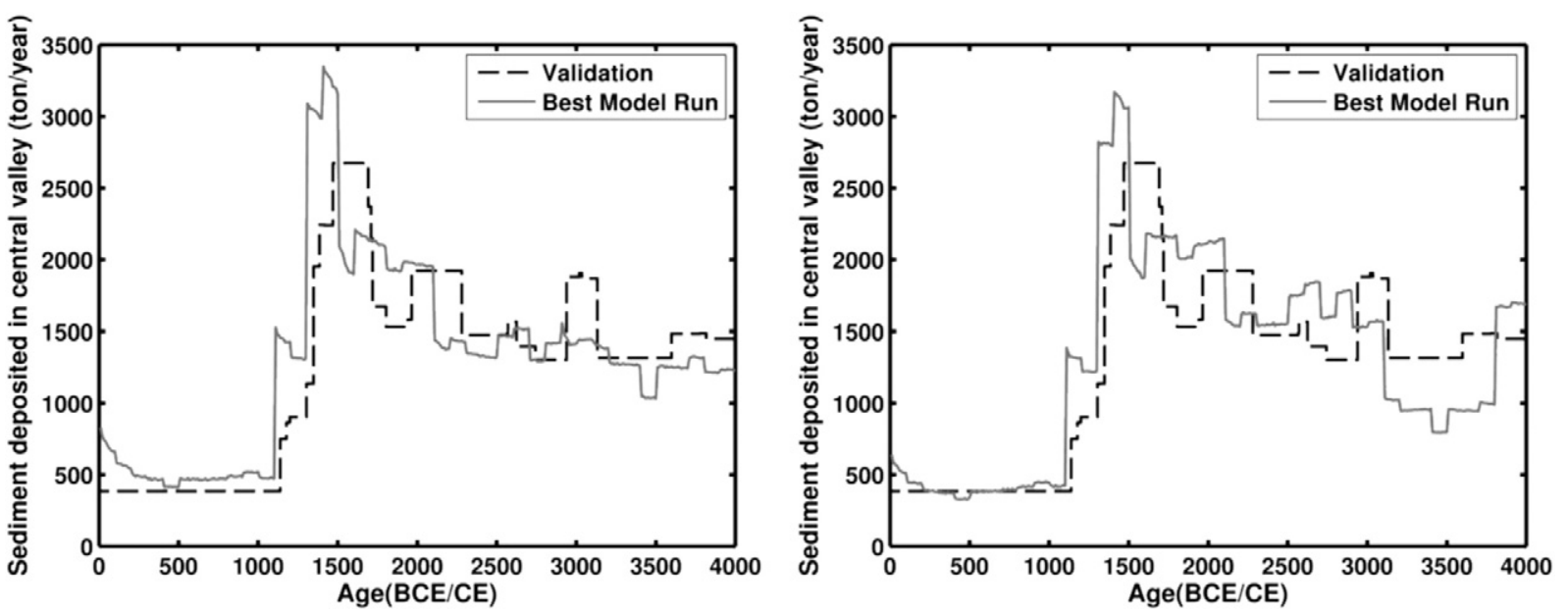

Fig. 18. Left: Model simulation with an alternative C-factor scenario. Right: Model simulation with a time variable ktc-factor.

\section{Conclusion}

The application of an adapted WATEM/SEDEM model in the Eastern Mediterranean shows that a geomorphic model can provide valuable information concerning the impact of Late Holocene environmental changes on the geomorphic system in this region. This study also shows that a model not at all developed for the region needs only minor adaptations in order to provide satisfying results. However, in order to be able to properly calibrate the geomorphic model, a detailed dataset of well-dated sediment archives is necessary. In the Gravgaz catchment, 12 cores were available with 33 radiocarbon dates, which was sufficient to reconstruct the valley sedimentation chronology over the last 4000 years. However, very few sites with such detailed quantitative records do exist (e.g. Dusar et al., 2011), again illustrating the need for more quantitative field-based studies on historic soil erosion (Verstraeten, 2014).

The model runs point out that land cover changes were the most influential driver of environmental change during the Late Holocene. Therefore, it can be stated that the geomorphic system response was largely caused by human activity in the Gravgaz catchment, rather than by natural variations in driving forces. Although climatic variations did have a discernible impact, it is not the major driver of sediment delivery to the Gravgaz valley bottom. Another important observation is the feedback mechanism of the soil reservoir and it's stone cover on the hillslopes. Limestone soils are progressively depleted over time with ongoing soil erosion, causing a reduction in sediment delivery. However, model results suggest that the soil depletion in the Gravgaz catchment did not have an exclusively negative impact on society, since at least a part of the loss in crop yield due to soil erosion is compensated by an increase in soil productivity in the lower lying valleys through soil accumulation. Despite the preliminary nature of the crop yield calculation at this stage, we do believe that this model approach is able to quantify human impact in the past and go beyond qualitative descriptions, which should ultimately lead to better understanding of human-environment interactions.

\section{Acknowledgments}

This research is funded by the Interuniversity Attraction Poles Program IAP 06/22 and 07/09, initiated by the Belgian Science Policy Office and by the Concerted Action of the Flemish Government (GOA project no. 3H051017). The support of the Centre for Archaeological Science at the KU Leuven is also gratefully acknowledged. Moreover, we thank Marc Waelkens, Jeroen Poblome and other staff members of the Sagalassos Archaeological Research Project for their administrative and logistic support during the field campaigns. The support of Katrijn
Dirix, Benjamin Campforts, Iris Deliever, Elena Marinova and Véronique De Laet during fieldwork is also greatly appreciated. Most of the sedimentological data which we relied upon were previously gathered and analysed by Etienne Paulissen, Simon Six and Marleen Vermoere.

\section{References}

Alatorre, L.C., Beguería, S., García-Ruiz, J.M., 2010. Regional scale modeling of hillslope sediment delivery: a case study in the Barasona Reservoir watershed (Spain) using WATEM/SEDEM. J. Hydrol. 391 (1-2), 109-123.

Araus, J.L., Ferrio, J.P., Voltas, J., Aguilera, M., Buxó, R., 2014. Agronomic conditions and crop evolution in ancient Near East agriculture. Nat. Commun. 5, 1-9.

Arnoldus, J.M.J., 1977. Methodology used to determine the maximum potential average annual soil loss due to sheet and rill erosion in Morocco. FAO Soils Bulletin 34, pp. 39-51.

Baartman, J.E.M., Masselink, R., Keesstra, S.D., Temme, A.M., 2013. Linking landscape morphological complexity and sediment connectivity. Earth Surf. Process. Landf. 38, 1457-1471.

Bakker, M.M., Govers, G., Ewert, F., Rounsevell, M.D.A., 2005. The crop productivity-erosion relationship: an analysis based on experimental work. Catena 57, 55-76.

Bakker, J., Paulissen, E., Kaniewski, D., De Laet, V., Verstraeten, G., Waelkens, M., 2011. Man, vegetation and climate during the Holocene in the territory of Sagalassos, Western Taurus mountains, SW Turkey. Veget. Hist. Archaeobot. http://dx.doi.org/10. 1007/s00334-011-0312-4.

Bakker, J., Paulissen, E., Kaniewski, D., Poblome, J., De Laet, V., Verstraeten, G., Waelkens, M., 2013. Climate people fire and vegetation new insights into vegetation dynamics in the Eastern Mediterranean since the 1st century AD. Clim. Past 9, 57-87.

Beach, T., Dunning, N., Luzzadder-Beach, S., Cook, D.E., Lohse, J., 2006. Impacts of the ancient Maya on soils and soil erosion in the central Maya Lowlands. Catena 65, $166-178$.

Bintliff, J., 2002. Time, process and catastrophism in the study of Mediterranean alluvial history: a review. World Archaeol. 33 (3), 417-435.

Bouwer, L.M., Aerts, J.C.J.H., Van de Coterlet, G.M., Van de Giesen, N., Gieske, A., Mannaerts, C., 2004. Evaluating downscaling methods for preparing Global Circulation Model (GCM) data for hydrological impact modelling. In: Aerts, J.C.J.H., Droogers, P. (Eds.), Climate Change in Contrasting River Basins. Adaptation Strategies for Water, Food and Environment. CABI Publishing, Wallingford, pp. 25-47.

Box Jr., J.E., 1981. The effects of surface salty fragments on soil erosion by water. Soil Sci. Soc. Am. J. 45, 111-116.

Buis, E., Temme, A.J.A.M., Veldkamp, A., Boeken, B., Jongmans, A.G., van Breemen, N., Schoorl, J.M., 2010. Shrub mound formation and stability on semi-arid slopes in the Northern Negev Desert of Israel: a field and simulation study. Geoderma 156, 363-371.

Butzer, K.W., Harris, E.S., 2007. Geoarchaeological approaches to the environmental history of Cyprus: explication and critical evaluation. J. Archaeol. Sci. 34, 1932-1952.

Butzer, K.W., 2005. Environmental history in the Mediterranean world: cross-disciplinary investigation of cause-and-effect for degradation and soil erosion. J. Archaeol. Sci. 32, 1773-1800.

Butzer, K.W., 2012. Collapse, environment, and society. PNAS 109, 3632-3639.

Coulthard, T., 2001. Landscape evolution models: a software review. Hydrol. Process. 15, 165-173.

Coulthard, T., Kirkby, M., Macklin, M., 1997. Modelling hydraulic sediment transport and slope processes at a catchment scale using a cellular automaton approach. Proceedings GeoComputation '97 \& SIRC '97, pp. 15-24.

Dean, J.R., Jones, M.D., Leng, M.J., Noble, S.R., Metcalfe, S.E., Sloane, H.J., Sahy, D., Eastwood, W.J., Roberts, C.N., 2015. Eastern Mediterranean hydroclimate over the late glacial and Holocene, reconstructed from the sediments of Nar lake, central Turkey, using stable isotopes and carbonate mineralogy. Quat. Sci. Rev. 124, 162-174. 
Dearing., J.A., Jones, R.T., 2003. Coupling temporal and spatial dimensions of global sediment flux through lake and marine sediment records. Glob. Planet. Chang. 39, 147-168.

de Moor, J., Verstraeten, G., 2008. Alluvial and colluvial sediment storage in the Geul River catchment (The Netherlands) - combining field and modelling data to construct a Late Holocene sediment budget. Geomorphology 95, 487-503.

de Vente, J., Poesen, J., Verstraeten, G., Van Rompaey, A., Govers, G., 2008. Spatially distributed modelling of soil erosion and sediment yield at regional scales in Spain. Glob. Planet. Chang. 60, 393-415.

Dotterweich, M., 2013. The history of human-induced soil erosion: geomorphic legacies, early descriptions and research, and the development of soil conservation-a global synopsis. Geomorphology 201, 1-34.

Desmet, P., Govers, G., 1995. GIS-based simulation of erosion and deposition patterns in an agricultural landscape: a comparison of model results with soil map information. Catena 25, 389-401.

D'Haen, K., Dusar, B., Verstraeten, G., Degryse, P., De Brue, H., 2013. A sediment fingerprinting approach to understand the geomorphic coupling in an eastern Mediterranean mountainous river catchment. Geomorphology 197, 64-75.

Dirix, K., 2010. Geochemische en mineralogische studie van de Holocene sedimenten in het bekken van Gravgaz (Turkije): karakterisering en bepaling van het herkomstgebied Unpublished master thesis K.U. Leuven 115 pp.

Dusar, B., Verstraeten, G., Notebaert, B., Bakker, J., 2011. Holocene environmental change and its impact on sediment dynamics in the Eastern Mediterranean. Earth-Sci. Rev. $108,137-157$

Dusar, B., Verstraeten, G., D'Haen, K., Bakker, J., Kaptijn, E., Waelkens, M., 2012. Sensitivity of the Eastern Mediterranean geomorphic system towards environmental change during the Late Holocene: a chronological perspective. J. Quat. Sci. 27 (4), 371-382.

Govers, G., Van Oost, K., Poesen, J., 2006. Responses of a semi-arid landscape to human disturbance: A simulation study of the interaction between rock fragment cover soil erosion and land use change. Geoderma 133, 19-31.

Grieser, J., Gommes, R., Bernardi, M., 2006. New LocClim - the Local Climate Estimator of FAO. Geophys. Res. Abstr. 8, 1607-7962.

Hancock, G., Lowry, J., Coulthard, T., Evans, K., Moliere, D., 2010. A catchment scale evaluation of the SIBERIA and CAESAR landscape evolution models. Earth Surf. Process. Landf. 35, 683-875.

Heimsath, A.M., Dietrich, W.E., Nishiizumi, K., Finkel, R.C., 1999. Cosmogenic nuclides, topography, and the spatial variation of soil depth. Geomorphology 27, 151-172.

Hoffmann, T., Lang, A., Dikau, R., 2008. Holocene river activity: analysing C-14-dated fluvial and colluvial sediments from Germany. Quat. Sci. Rev. 27, 2031-2040.

Hughes, J.D., Thirgood, J.V., 1982. Deforestation, erosion, and forest management in ancient Greece and Rome. J. For. Hist. 26 (2), 60-75.

Hutchinson, J., 1969. Erosion and land use: the influence of agriculture on the Epirus Region of Greece. Agric. Hist. Rev. 17 (2), 85-90.

Irvem, A., Topaloglu, F., Uygur, V., 2007. Estimating spatial distribution of soil loss over Seyhan River Basin in Turkey. J. Hydrol. 336, 30-37.

Kaniewski, D., De Laet, V., Paulissen, E., Waelkens, M., 2007. Long-term effects of human impact on mountainous ecosystems, western Taurus Mountains, Turkey. J. Biogeogr. 34, 1975-1997.

Keesstra, S.D., Bruijnzeel, L.A., van Huissteden, J., 2009. Meso-scale catchment sediment budgets: combining field surveys and modeling in the Dragonja catchment, southwest Slovenia. Earth Surf. Process. Landf. 34 (11), 1547-1561.

Kosmas, C., Gerontidis, S., Marathianou, M., Detsis, B., Zafiriou, T., Muysen, W.V., Govers, G., Quine, T., Vanoost, K., 2001. The effects of tillage displaced soil on soil properties and wheat biomass. Soil Tillage Res. 58, 31-44.

Lee, S., Cruse, R., 2015. Topsoil depth effects on crop yields as affected by weather. Geophys. Res. Abstr. 17 EGU2015-6577.

Lowdermilk, W.C., 1953. Conquest of the land through 7,000 years. U.S. Department of Agriculture, Soil Conservation Service, Agriculture Information Bulletin 99. GPO, Washington, DC.

McAnany, P., Yoffee, N., 2010. Questioning Collapse. Human Resilience, Ecological Vulnerability, and the Aftermath of Empire. Cambridge University Press, Cambridge.

McNeill, J.R., 1992. The Mountains of the Mediterranean World: An Environmental History. Cambridge University Press, New York, 358 pp.

McNeill, J.R., Winiwarter, V., 2004. Breaking the sod: humankind, history, and soil. Science 304, 1627-1629.

Montgomery, D., 2007. Soil erosion and agricultural sustainability. PNAS 104, 13268-13272.

Minasny, B., Finke, P., Stockmann, U., Vanwalleghem, T., McBratney, A.B., 2015. Resolving the integral connection between pedogenesis and landscape evolution. Earth Sci. Rev. 150, 102-120.

Mitchell, T., Carter, T.R., Jones, P., Hulme, M., 2003. A comprehensive set of high-resolution grids of monthly climate for Europe and the globe: the observed record (1901 - 2000) and 16 scenarios (2001 - 2100). Tyndall Centre Working Paper 55, pp. 1-30.

Notebaert, B., Verstraeten, G., 2010. Sensitivity of West and Central European river systems to environmental changes during the Holocene: a review. Earth Sci. Rev. 103, 163-182.

Notebaert, B., Verstraeten, G., Ward, P., Renssen, H., Van Rompaey, A., 2011. Modeling the sensitivity of sediment and water runoff dynamics to Holocene climate and land use changes at the catchment scale. Geomorphology 126, 18-31.

Paulissen, E., Poesen, J., Govers, G., de Ploey, J., 1993. The physical environment at Sagalassos (Western Taurus, Turkey). A reconnaissance survey. In: Waelkens, M., Poblome, J. (Eds.), Sagalassos II, Report on the Third Excavation Campaign of 1992, Acta Archaeologica Lovaniensa Monographiae 6. Leuven University Press, Leuven, pp. 229-248.

Peeters, I., Rommens, T., Verstraeten, G., Govers, G., Van Rompaey, A., Poesen, J., Van Oost, K., 2006. Reconstructing ancient topography through erosion modelling. Geomorphology 78, 250-264.
Peeters, I., 2007. Spatial Modeling of Sediment Redistribution on a Millennial Time Scale Ph.D. Thesis K.U. Leuven, Department of Geography-Geology, Leuven, Belgium.

Peeters, I., Van Oost, K., Govers, G., Verstraeten, G., Rommens, T., Poesen, J., 2008. The compatibility of erosion data at different temporal scales. Earth Planet. Sci. Lett. $265,138-152$.

Poesen, J., Torri, D., Bunte, K., 1994. Effect of rock fragments on soil erosion by water at different spatial scales: a review. Catena 23, 141-166.

Raes, D., Steduto, P., Hsiao, T.C., Fereres, E., 2009. AquaCrop-the FAO crop model to simulate yield response to water: II. Main algorithms and software description. Agron. J. 101 (3), 438-447.

Renssen, H., Seppä, H., Heiri, O., Roche, D.M., Goosse, H., Fichefet, T., 2009. The spatial and temporal complexity of the Holocene thermal maximum. Nat. Geosci. 2, 411-414.

Roberts, N., Meadows, M.E., Dodson, J.R., 2001. The history of Mediterannean-type environments: climate, culture and landscape. The Holocene 11, 631-634.

Rustomji, P., Prosser, I., 2001. Spatial patterns of sediment delivery to valley floors: sensitivity to sediment transport capacity and hillslope hydrology relations. Hydrol. Process. 15, 1003-1018.

Six, S., Paulissen, E., Van Thuyne, T., Lambrechts, J., Vermoere, M., De Laet, V., Waelkens, M., 2008. Late Holocene sediment characteristics and sediment accumulation in the marsh of Gravgaz: evidence for abrupt environmental changes. In: Degryse, P. Waelkens, M. (Eds.), Sagalassos VI. Geo- and Bio-Archaeology at Sagalassos and in Its Territory. Leuven University Press, Leuven, pp. 189-210.

Schwartz, G.M., Nichols, J.J., 2006. After Collapse: The Regeneration of Complex Societies. The University of Arizona Press, p. 289.

Steduto, P., Hsiao, T.C., Raes, D., Fereres, A.C.E., 2009. The FAO crop model to simulate yield response to water: I. Concepts and underlying principles. Agron. J. 101, 426-437.

Temme, A.J.A.M., Schoorl, J.M., Veldkamp, A., 2006. Algorithm for dealing with depressions in dynamic landscape evolution models. Comp. Geosci. 32, 452-461.

Trimble, S., 1999. Decreased rates of alluvial sediment storage in the Coon Creek Basin, Wisconsin. Science 285, 1244-1246.

Van Andel, T.H., Runnels, C.N., Pope, K.O., 1986. Five thousand years of land use and abuse in the Southern Argolid, Greece. Hesperia 55 (1), 103-128.

Van Andel, T.H., Zangger, E., Demitrack, A., 1990. Land use and soil erosion in prehistoric and historical Greece. J. Field Archaeol. 17 (4), 379-396.

Vandenberghe, J., 2012. Multi-proxy analysis: a reflection on essence and potential pitfalls. Neth. J. Geosci. 91 (1-2), 263-269.

Van Oost, K., Govers, G., Desmet, P.J.J., 2000. Evaluating the effects of changes in landscape structure on soil erosion by water and tillage. Landsc. Ecol. 15, 577-589.

Van Rompaey, A., Verstraeten, G., Van Oost, K., Govers, G., Poesen, J., 2001a. Modelling mean annual sediment yield using a distributed approach. Earth Surf. Process. Landf. 26 (11), 1221-1236.

Van Rompaey, A., Verstraeten, G., Van Oost, K., Rozanov, A., Govers, G., Poesen, J., 2001b. Modelling sediment transport in the Jonkershoek catchment: part 1: model calibration and validation. In: Govers, G., Van Meirvenne, M., Poesen, J., Gabriëls, D. Rozanov, A., Laker, M.C., Van Oost, K. (Eds.), Cartographic Modelling of Land Degradation, Proceedings of the Workshop Held in Ghent (September 2001) in the Framework of the Bilateral Co-operation Between Flanders and South-Africa, pp. 75-89.

Vermoere, M., Smets, E., Waelkens, M., Vanhaverbeke, H., Librecht, I., Paulissen, E., Vanhecke, L., 2000. Late Holocene environmental change and the record of human impact at Gravgaz near Sagalassos, southwest Turkey. J. Archaeol. Sci. 27, 571-595.

Vermoere, M., Bottema, S., Vanhecke, L., Waelkens, M., Paulissen, E., Smets, E., 2002. Palynological evidence for late-Holocene human occupation recorded in two wetlands in SW Turkey. The Holocene 12 (5), 569-584.

Verstraeten, G., Van Oost, K., Van Rompaey, A., Poesen, J., Govers, G., 2002. Evaluating an integrated approach to catchment management to reduce soil loss and sediment pollution through modelling. Soil Use Manag. 18, 386-394.

Verstraeten, G., Prosser, I.P., Fogarty, P., 2007. Predicting the spatial patterns of hillslope sediment delivery to river channels in the Murrumbidgee catchment, Australia. J. Hydrol. 334, 440-454.

Verstraeten, G., 2009. Human impact on sediment dynamics - quantification and timing. Catena 77, 77-80.

Verstraeten, G., 2014. Quantification of human-environment interactions in the past Anthropocene 8, 1-5.

Vita-Finzi, C., 1969. The Mediterranean Valleys: Geological Changes in Historical Times. Cambridge University Press, Cambridge.

Waelkens, M., Poblome, J., 1993. Sagalassos II, report on the third excavation campaign of 1992. Acta Archaeologica Lovaniensa Monographiae 6, Leuven University Press, Leuven, 278 pp.

Waelkens, M., Paulissen, E., Vermoere, M., Degryse, P., Celis, D., Schroyen, K., De Cupere, B., Librecht, I., Nackaerts, K., Vanhaverbeke, H., Viaene, W., Muchez, P., Ottenburgs, R., Deckers, S., Van Neer, W., Smets, E., Govers, G., Verstraeten, G., Steegen, A., Cauwenberhs, K., 1999. Man and environment in the territory of Sagalassos, a classical city in SW Turkey. Quat. Sci. Rev. 18, 697-709.

Ward, P.J., Aerts, J.C.J.H., De Moel, H., Renssen, H., 2007. Verification of a coupled climatehydrological model against Holocene palaeohydrological records. Glob. Planet. Chang. 57, 283-300.

Ward, P.J., van Balen, R.T., Verstraeten, G., Renssen, H., Vandenberghe, J., 2009. The impact of land use and climate change on late Holocene and future susptended sediment yield of the Meuse catchment. Geomorphology 103, 389-400.

Widlok, T., Aufgebauer, A., Bradtmöller, M., Dikau, R., Hoffmann, T., Kretschmer, I., Panagiotopoulos, K., Pastoors, A., Peters, R., Schäbitz, F., Schlummer, M., Solich, M., Wagner, B., Weniger, G.-C., Zimmermann, A., 2012. Towards a theoretical framework for analyzing integrated socio-environmental systems. Quat. Int. 274, 259-272.

Yaalon, D.H., 1997. Soils in the Mediterranean region: what makes them different? Catena 28, 157-169. 